\title{
THE RIGHTS OF MAN IN THE WORLD COMMUNITY: CONSTITUTIONAL ILLUSIONS VERSUS RATIONAL ACTION
}

\author{
Myres S. McDougal* and Gertrude C. K. Leighton $\dagger$
}

"It was a great day for the human race ... . when the idea dawned that every man is a human being, an end in himself, with a claim for the development of his own personality, and that human beings had a dignity and a worth, respect for which is the firm basis of human association."

\section{Charles E. Merriam, Systematic Politics 59 (1945).}

"The Independence of America, considered merely as a separation from England, would have been a matter of but little importance, had it not been accompanied by a Revolution in the principles and practices of Governments. She made a stand, not for herself only, but for the world, and looked beyond the advantages herself could receive."

Thomas Paine, The Rights of Man I5I (I792) (Everyman's ed.)

It is only from a perspective of centuries that the United Nations program for "human rights" can be accurately observed or rationally appraised. This program, too often thought to be at the periphery of the purposes of the United Nations, represents in fact the main core of rational objectives not only of the United Nations but of all democratic government. ${ }^{1}$ It represents the converging and integration on a global scale of many movements, movements hitherto restricted in areal diffusion but centuries-old and rooted deep in universal human nature and civilized culture. ${ }^{2}$ It is heir to all the great historic democratic movements-for constitutionalism, freedom, equality, fraternity, humanitarianism, liberalism, enlightenment, peace, opportunity, and so on. ${ }^{3}$ It is the contemporary culmination of man's long struggle for all his basic human values:

* M.A., LL.B., B.C.L., J.S.D. William K. Townsend Professor of Law, Yale Law School. Formerly Assistant General Counsel, The Lend Lease Administration, and General Counsel, The Office of Foreign Relief and Rehabilitation Operations. Author of various books and articles.

† A.B., LL.B. Visiting Lecturer in Law, Yale Law School. Member of the New York bar. Formerly associated with Carter, Ledyard, and Milburn, New York City, and Note Editor, The YaLe Law Jounnal Contributor to legal periodicals.

${ }^{2}$ Carl L. Becker, Modern Democracy (i94I); Charles E. Merriam, Sistentattc Politics c. 2 (1944).

To Secure These Rights, The Report of the President's Committee on Civil Rigitts (1947) appropriately has for its frontispiece the words from the Declaration of Independence: ". . . to secure these rights governments are instituted among men. ..." Cf. Jefferson to Madison: "A bill of rights is what the people are entitled to against every government on earth, general or particular; and what no just government should refuse or rest on inferences." 4 Writings of Thomas Jeffenson 477 (Ford cel. I894).

2 Bronislaw Malinowski, Freedom and Civilization (1944); Gardner Murphy (Ed.), Human Nature and Enduring Peace (I945); Gardner Murphy, Personality 905 et seq. (1947).

${ }^{3}$ Hersh Lauterpacht, AN International Bill of tile Rights of Man 3-65 (1945), and Preliminary Report to Internationat, Law Associatton, Brussels Conference (1948): A. N. Holconene, Human Rights in the MOdern World c. 2 (1948); Acton, Freedom in Antiquity in History of Free- 
for participation in the processes by which he is governed, equality before the law, and that wide sharing of power, both formal and real, which we call democracy;

for sanctity of person, for freedom from arbitrary restraints and cruel and inhuman punishments, and for positive opportunity to develop latent talents for the enrichment and well-being of personality;

for the enlightenment by which rational decisions can be made and for freedom of inquiry and opinion;

for that fundamental respect for human dignity which both precludes discrimination based on race, sex, color, religion, political opinion, or other ground irrelevant to capacity and provides positive recognition of common merit as a human being and special merit as an individual;

for access to resources to produce the goods and services necessary to maintain rising standards of living and comfort;

for acquisition of the skills necessary to express talent and to achieve individual and community values to the fullest;

for freedom to explain life, the universe, and values, to fix standards of rectitude, and to worship God or gods as may seem best;

for affection, fraternity, and congenial personal relationships in groups freely chosen;

for, in sum, a security which includes not only freedom from violence and threats of violence but also full opportunity to preserve and increase all values by peaceful, noncoercive procedures. ${ }^{4}$

It is for values such as these that men have always framed constitutions, established governments, and sought that delicate balancing of power and formulation of fundamental principle necessary to preserve human rights against all possible aggressors, governmental and other. ${ }^{5}$ The United Nations taken as a wholeCharter, organization and practice-is but man's latest effort, though with a grander vision and on a more comprehensive scale than ever before. It is commonly agreed, as the Charter states, ${ }^{6}$ that the principal purpose for which the United Nations was established is the maintenance of "international peace and security." Throughout the Charter, however, runs the wise recognition, which pervaded all the great declarations of war aims and general consciousness of mankind, that peace and security, even in the limited sense of freedom from physical violence, cannot be obtained by arbitrary fiat and sheer balancing of power. ${ }^{7}$ A peace to

dom aNd Other Essays (Figgis and Lawrence Eds. I922); Georg Jellinek, The Declaration of the Rights of Man and of Citizens; A Contribution to Modern Constitutional History (Farrand Tr. igor); Fernando, An International Bill of Human Rights (i948); Laski, Democracy, 5 Encyc. Soc. Scr. 76 (1931); Shephard, Government, 7 id. at 8 (1932); Brinton, Equality, 5 id. at 574 (1931); Ruggiero, Liberalism, 9 id. at 435 (I933); Thomas V. Smith, The Promise of American Politics (1936); George E. Sabine, A History of Political Theory (i937); John L. Randall, The Making of the MODERN MiNd (rev. ed. 1940).

- For the utility in systematic analysis of this particular categorization of values, see HAROLD D. LAssweld, Power and Personality (1948); Lasswell and McDougal, Legal Education and Public Policy; Professional Training in the Public Interest, 52 YALE L. J. 203, 217 (1943); McDougal, The Role of Law in World Politics, 20 Miss. L. J. 253 (1949).

[ Charles H. Mcilivain, Constitumonalism: Ancient and Modern (rev. ed. 1947), and Constitumonalism and the Changing World (1939); Hamilton, Constitutionalism, 4 Encyc. Soc. Sci. 255 (i93I); Edward S. Corwin, Liberty Against Government (1948).

${ }^{\circ}$ Charter of thf. United Nations, Preamble and Article i (Dep't State Pub. No. 2353, Conference Series 74, 1945).

${ }^{7}$ Leland M. Goodrich and Edvard Hambro, Charter of the United Nations: Commentary and Documents 93, 319 ( $2 \mathrm{~d}$ and rev. ed. I949). 
endure must include the conditions of peace and a reduction of the severe frustrations that drive men to violence. ${ }^{8}$ Some deprivations and threats of external dictation men find more intolerable than war. Peace as the common man conceives it includes more than freedom from war and threats of war: it includes the freedom, without external dictation from any arbitrary power, to maintain and enhance by peaceful, non-coercive procedures the value positions both of himself and of all others with whom he identifies. ${ }^{\vartheta}$ Hence the United Nations Charter insists upon a peace "in conformity with the principles of justice and international law," states among its major purposes the achievement of "international cooperation in solving international problems of an economic, social, cultural, or humanitarian character, and in promoting and encouraging respect for human rights and for fundamental freedoms for all without distinction as to race, sex, language, or-religion,"10 and both imposes a definite legal obligation upon its member states to promote this objective and establishes a machinery of its own to take further measures.

The intensification within recent centuries, most notably since the industrial revolution, of the demands of the individual human being for security in the full sense indicated above, for the greater production and sharing of all values, and especially for respect, in the sense both of equality of access to all values and of symbolic recognition of this equality, is a matter of common observation. ${ }^{11}$ The basic trend in demand and community response has been well characterized as the "fundamental democratization of society."12 The evidences of a major movement from caste society to free society are written large in both doctrine and practice. All of the great post-feudal philosophies, from liberal capitalist through socialist and excluding only the totalitarian, have stressed the fundamental dignity of the individual human being and demanded its realization in practice. Stimulated by modern science and technology and by a growing uniformity in world attention and attitudes, practice has responded in recent generations with wholesale liquidation of discriminations based on caste exclusions and in a great rise in community activities designed to provide individuals with any necessary compensating assistance required to raise them to minimum levels and to afford positive opportunities for maturing latent talents into socially valued expression. One could point to such

\footnotetext{
${ }^{8}$ Gardner Murphy (Ed.), Human Nature and Endurting Peace 29 (1945): “. . . the risk of war is so great that the over-all strategy of peace calls for the reduction of scvere frustrations rather than the futile effort to extirpate aggression by fiat, discipline, or punishment."

${ }^{8}$ The latest authoritative reaffirmation of this conception appears in the preamble of the North Atlantic Security Pact, which reads that the "parties to this treaty" are "determined to safeguard the freedom, common heritage and civilization of their peoples, founded on the principles of democracy, individual liberty and the rule of law." (Dep't State Pub. No. 3464 , General Foreign Policy Series 8, I949).

${ }_{10}$ U. N. Charter Art. I.

${ }^{11}$ For systematic review see Lasswell, The Interrelations of World Organization and Society, 55 YALE L. J. 889 (1946). See also Richard H. Tawnex, Equality (I93I); Eric J. Dingwell, Racial Pride and Prejudice (1946); Harold F. Gosnell, Democracy: The Threshold of Freedom (1948); Louis Le Fevre, Liberty and Restraint (T93 I); Frederick L. Schumian, International Politics 540 (4th ed. I948); I QUINCY WRIGHT, A STUDY OF WAR I70 (1942).

12 Karl Mannheim, Man and Soctety in an Age of Reconstruction 44 (1940).
} 
items as the extension of suffrage and improvement in representation techniques; the creation of a free school system and the expansion of facilities for communication; protections against arbitrary restraint and the amelioration of punishment; provision of respected jobs at minimum wages and shorter hours of work; conscious community planning of resource use and development; provision of better housing and proper medical care; unemployment programs and employment and health insurance; social security; improvement of facilities for recreation; and many more. With the new stimulus of promise and threat in the development of atomic energy, it is not to be expected that common men the world around will reduce their demands. Short of world tyranny and intimidation, it can, on the contrary, be safely predicted that they will both increase and still further intensify their demands.

It is a commonplace in a world threatened by new war and atomic destruction that all peoples everywhere are today interdependent for securing all their basic demands, that mankind today lives in what is in fact a world community. It is a familiar history, often recounted, how many changes-changes in population; changes in the attitudes, identifications, and expectations of people; changes in techniques of organization and institutional practices; and most important of all, changes in technology, the railroad, steamship, and airplane, the press and telecommunications, and now atomic energy-have transformed the world from relatively independent, discrete localities into a congeries of interacting regional communities and a single world community. ${ }^{13}$ It may, however, be conducive to clarity to mark out the main outlines of peoples' interdependences with respect to security and all the other values which we sum up as "human rights." The most decisive value process in the world community is the world power process in which the nation-state is still the predominant participant. How power is structured internally in a nation-state, how the individual human being is related to centrally organized coercion, affects very directly how that nation-state seeks to exercise power in the world arena, whether by violence or peaceful procedures. It has been observed that the Nazi leaders rose to power by the systematic suppression of civil liberties at home; $;^{14}$ the violence they brought to the world arena still sears mankind.

\footnotetext{
${ }^{13}$ Ralph B. Perry, One World in the Making (I945) ("Dedicated to the Memory of Wendell Willkie the First Prviate Citizen of that One World Which Having Discovered for Himself He Disclosed to His Fellow-Americans"); Wright, Accomplishments and Expectations of World Organization, 55 Yale L. J. 870 (1946); Quincy Wright (Ed.), The World Community (1948); Mannheim, op. cit. supra note 12, at 49; Emery Reves, The Anatomy of Peace (I945); Cord Meyer, Peace or Anarchy (1945); William L. Borden, There Will Be No Time (1946); University of Denver, Foundations For World Order (I949); Willian F. OgBurn (Ed.), Teghology and International Relattons (I949); Hans W. Weigert, Vilhjaldur Stefansson and Ruchard E. Harrison (Eds.), New Compass of the World (1949); LyMan Bryson, Louis Finkiestein, and Robert M. Makiver (Eds.), Approaches to World Peace (I944); Ralph Linton (ED.), Most of the World (1949); Murdock, Knauth, and Thayer, Law and Lawyers for One World in the Making, 16 Geo. Wash. L. R'Ev. 97 (1948).

i4 3 Sidney Post Simpson and Julius Stone, Cases and Readings on Law and Societr r595 (1949): "Fistorically German Fascism rose to power by deliberately destroying the liberties achieved under German democracy ..." A graphic account of the internal deprivation of human rights and of its connection with preparation for external aggressions appears in the Judgment of the Nuremberg Tribunal.

In Effects of International Tension on Liberty Under Law, 48 CoL. L. Rev. 555, 558 (I948), Fritz
} 
History too recent makes it clear that elites who come to power and maintain internal rule by violence are prone to regard violence as the principal instrument of international change; in complement, their intimidated masses are all too ready to turn their forcibly repressed and accumulated hatreds against their fellow men, across some arbitrary boundary line. ${ }^{15}$ Conversely, the respect for individual human dignity which even a democratic nation-state can maintain is in large measure a function of that state's position in a total world context. When expectations of violence and war are high, the requirements of self-preservation may move even the best-intentioned toward a "garrison-prison" state. ${ }^{16}$ In the age of the shattered atom and rumored bacteriological horrors, when all nation-states are so obsessed by expectations of impending violence that they must calculate every proposed measure of cooperation about wealth, enlightenment, or human rights generally in terms of possible effects on fighting power, it takes no great insight to know that no people can be secure unless all people are secure and possess all the conditions of security.

Interdependences comparable to the kind outlined for the world power process could be indicated for every other world value process. Documentation could be offered both territorially, with respect to each value around the globe, and functionally, as between all values. ${ }^{17}$ A few suggestions must suffice. Thus, with respect to wealth, just as measures for economic improvement must be assayed in terms

Morstein Marx generalizes: "As a political system dedicated to the categorical imperatives of a secular religion, totalitarianism is essentially expansionist. It is missionary in spirit and messianic in aspirations." He develops the theme in Totalitarian Politics, 82 Proc. AM. Phil. Soc. I (I940).

${ }^{15}$ In a chapter on The Emotional Structure of Totalitarianism in his OUR AGE OP UNREAson (1942),

Franz Alexander offers profound analysis of the relevant psychological factors. He summarizes:

"A peculiarly vicious circle in socio-dynamics can be observed herc. $\Lambda$ n authoritarian state is created which deprives its citizens of self-expression in the interests of cconomic competition with other nations. This injury to self-esteem requires aggressive action and war becomes an inevitable compensation. Diplomatic victories achicved by compromise no longer suffice, for the heroic life of conquest and domination for their own sake and the myth of the superior race are incompatible with anything but martial victory. In order to make some compensation to those who have lost their normal means of self-expression, the ideology of the victorious super race was invented. This was an appeal to the destructive emotional forces in human nature, especially hate, which had been simmering for years in an impoverished and over-disciplined people who had been forced to sacrifice butter for guns, individual expression for cringing subordination, self-estcem for awe, and conscience for blind obedience. This hate was generated in the barracks under the sadistic drill of the sergeants, in the factories by the abolition of recently acquircd political rights, in a demoralized middle-class which had sunk to the level of the proletariat and needed someone to look down upon as inferior. The awakened Frankenstein's monster of hate must move against the rest of humanity to save the Führer and his small camarilla from destruction. Hate once mobilized knows no barriers and cares little who are its victims. If an object is lacking, it may even react against the hater himself and occasion suicide."

${ }^{10}$ Lasswell, supra note $\mathrm{Ix}$.

In a speech at Monticello on July 4, 3947 , President Truman stated: "So long as the basic rights of man are denied in any substantial portion of the earth, men everywhere must live in fear of their own rights and their own security." I7 Dep't STATE Bull. 80, 81 (I947).

For more detailed discussion of the interdependences of human rights and security, sec Wright, The Rights of Man, 3 U. N. WEEKLY BuLL. 777 (1947).

${ }^{17}$ For development of the interdependences here sketched see McDougal, supra notc 4 . 
of their effects on power, so also because of the demands of people a rising standard of living everywhere is indispensable to security; and, further, because the economic cycle is now world-wide in its impact, depression in any significant area of the world makes it correspondingly difficult in all other areas to maintain high levels in the production and sharing of goods and, hence, the conditions under which liberty and human personality can flourish. Similarly, with respect to enlightenment, accurate knowledge of other peoples' attitudes, identifications, and expectations and a clear understanding of world-wide interdependences are indispensable to rational decisions about security and other values. Yet in a world increasingly divided and marked off by iron curtains, it is increasingly difficult for the free peoples of the world to acquire and spread the enlightenment necessary for rational decision. Finally, coming explicitly to the value respect itself, recent scientific studies confirm the common-sense notion that the degree to which men are treated with simple human dignity affects their every response, predisposing them either to violence, war, and revolution or to their utmost exertion in the peaceful production of values. ${ }^{18}$ One of the major factors in world politics today, affecting all decisions, is the accumulated resentment of countless millions of people, and even whole nations, arising from long endured discriminations, deprivations, and humiliations-a resentment capable of being discharged against many targets, internal and external. ${ }^{19}$ It may be recalled also that aggression, brutality, and violations of human dignity, such as devised by the Nazis, are as contagious as germs; models of disrespect for human dignity anywhere in the world can be copied everywhere. It is not too much, therefore, to summarize that because of man's deep, rising demands for consideration and because of all these interdependences, a world half-slave and half-free cannot endure. ${ }^{20}$

\footnotetext{
18 The classic work for basic principles and history of opinion is JoHn DOLLARD, Frustration AND AGGression (1939). Among the more important experimental studies of the fundamental significance of the respect factor are those conducted and inspired by Elton Mayo. For detailed references see ElToN Mayo, The Social Problems of an Industrial Civiluzation (1945), and Fritz J. Roethlisberger, Management and Morale (194I).
}

For general background see Sharp, Aggression, 57 Ermics I (1947); Chisholm, The Psychiatry of Enduring Peace, 6 Psychistry 3 (1946); Cook, Democratic Psychology and a Democratic World Order, I World Politics 553 (x949); EdWard Glover, War, Sadism, and Pacifism (I933); RANYard West, Psychology and Wordd Order (1945), and Conscience and Society (I945); Lasswell, supra note 4; Erich Fromim, Escape from Freedom (194I); John C. Flügel, MaN, Morals and Society (I945); Harry S. Sullivan, Conceptions of Modern Psychiatry (1947); Abram Kardiner, The Psychologtcal. Frontiers of Society (1945); II Prdc. Int. Conf. on Child Psychiatry (I948), for a series of papers on aggression.

10 Robert M. Maciver (Ed.), Civilization and Group Relationships 40 (1945). Alexander, op. cit. silpra note 15, at $21 \mathrm{I}$ : "When the organism is frustrated in the gratification of any of its basic needs, agressive behavior is the most common response. This is fundamentally an attempt to obtain the necessities of life by force."

See also Dingwall, op. cit. supra note i1; Harold D. Lasswell, Worlo Politics and Personal. INSECURITY, c. 5, Independence Movements: The Demand for Equality (I935); RUTH F. BENEDICT, RACE: Science and Politics (1943); Robert M. Maciver, The More Perfect Union (1948); Gunnar Myrdal, The American Dilemina (I944); Oliver C. Cox, Caste, Class, and Race (1948), with an introduction by Roucek: "Nothing has been more provocative of international ill will than problems springing from, and directly and indirectly related to, the phenomena of caste, class and race." Id, at xxvii.

${ }^{20}$ Lewis and Ellingston, introduction to Symposium on Essential Human Rights, 243 ANNALs (1946): "A world society possessed of limitless destructive power on wings must be organized to save the welfare and freedom of the individual human being or it will destroy itself." 
It is in the context of these demands and interdependences that the United Nations program for human rights was conceived and is being implemented. The structure of obligation assumed in the Charter embraces seven specific references to human rights. As in no like international treaty the "people," not the signatory states, of the United Nations reaffirm their "faith . . . in the dignity and worth of the human person, in equal rights of men and women. ..."21 The Purposes and Principles, already referred to, ${ }^{22}$ which have general application to the organization are particularized in the obligation of the General Assembly to initiate studies and make recommendations for the purpose of "promoting international cooperation in the economic, social, cultural, educational, and health fields, and assisting in the realization of human rights and fundamental freedoms for all without distinction as to race, sex, language, or religion." ${ }^{23}$ This undertaking is reiterated in Article 55 of Chapter IX, which concerns international economic and social cooperation. The obligation which looks to "the creation of conditions of stability and well-being which are necessary for peaceful and friendly relations among nations" binds both the General Assembly and the Economic and Social Council ${ }^{24}$ in clearly mandatory language ${ }^{25}$ to promoting "universal respect for, and observance of, human rights and fundamental freedoms for all without distinction as to race, sex, language, or religion." ${ }^{20}$ Like the General Assembly, the Economic and Social Council is also empowered to make recommendations to promote respect and "observance of" human rights, ${ }^{27}$ and to establish commissions for their promotion. ${ }^{28}$ The "basic objectives" of the trusteeship system is to "encourage respect for human rights" (and also to encourage, it should be noted, "recognition of the interdependence of the peoples of the world.") ${ }^{29}$ Not only are the various organs of the United Nations thus heavily obligated to satisfy demands for human rights, but the member states signatory to the Charter directly bind themselves. Article $5^{6}$ provides " $[\mathrm{A}] 11$ members pledge themselves to take joint and separate action in

${ }^{21}$ U. N. Charter, Preamble, supra note 6.

22 See supra note ro.

${ }^{2}$ U. N. Charter Art. 13 (r)(b).

${ }^{24} I d$. Art. 6o. "Responsibility for the discharge of the functions of the Organization set forth in this Chapter shall be vested in the General Assembly and, under the authority of the General Assembly, in the Economic and Social Council, which shall have for this purpose the powers set forth in Chapter X."

${ }^{35}$ Id. Art. 55: ". . . The United Nations shall promote . . ." (Italics supplied.)

${ }^{20} \mathrm{Id}$. Art. 55. This Article along with Articles ${ }_{3} 3$ and 62 was enlarged in the course of the San Francisco Conference to include a broader emphasis on human rights than had originally been the case in the provisions of the Dumbarton Oaks Proposals. See ix Dep'T State Bull. 368; Report' TO THE President on the Results of the San Francisco Conference, Heatings before the Senate Committee on Foreign Relations, 79th Cong., Ist Sess. 53, 102, 105, 108, 112-20 (1945).

The italicized words were added "to strengthen the statement by making it clear that something more than formal respect for the rights and freedoms in question is demanded." Goopricir and HAmmo, op. cit. supra note 7 , at 322 .

23 U. N. Charter Art. 62.

${ }^{28}$ Id. Art. 68 . The Commission on Human Rights is one of the few commissions expressly authorized by the Charter.

${ }^{20} \mathrm{Id}$. Art. 76. 
cooperation with the Organization for the achievement of the purposes set forth in Article 55." These purposes it will be recalled include promoting "observance of" as well as general respect for human rights.

The execution of this program finds partial expression in the Genocide Convention, ${ }^{30}$ the Universal Declaration of Human Rights, ${ }^{31}$ the currently proposed International Covenant of Human Rights, ${ }^{32}$ and in various suggested measures for implementation and enforcement. ${ }^{33}$ The Genocide Convention and the Declaration of Human Rights, the one a treaty to be ratified, the other a declaration of policy and public affirmation addressed to member states, were approved by the General Assembly in December, I948. ${ }^{34}$ The Convention seeks to eradicate the ultimate deprivation of human rights: the destruction of national, ethnical, racial, or religious groups "as such." Inspired by frightful Nazi precedents, not only is killing members of a group on racial or other grounds prohibited but also the imposition of destructive conditions of life, the prevention of births, and other measures directed toward group extermination are banned. ${ }^{36}$ The scope of the Convention extends to public officials and rulers, as well as to private individuals, ${ }^{37}$ all of whom may in addition to the crime of genocide be indicted for conspiracy, attempt, and complicity in respect to genocide, and for "incitement" of the crime. ${ }^{38}$ Enforcement involves the undertaking by signatories to incorporate this newly devised international crime into domestic law, ${ }^{39}$ and to submit disputes as to interpretation, application, or fulfilment to the International Court of Justice. ${ }^{40}$ Other organs of the United Nations -the General Assembly, the Security Council-may be called upon to consider action for prevention or suppression of the crime. ${ }^{41}$ And it is contemplated that upon the establishment of an international penal tribunal persons charged with genocide may be brought before it, provided jurisdiction of such a court has been recognized by the contracting states. ${ }^{42}$

The Declaration, in contrast, does not purport to be an enforceable covenant, ${ }^{43}$

${ }^{30}$ See Dep't State Pub. No. 3416 (I949).

${ }^{31}$ See Dep't State Pub. No. 338 I (1949).

32 See Report of the Fifth Session of the Commission on Human Rights to the Economic and Social Couvell, May 9-June 20, 1949, U. N. Doc. E/1371, Annex I.

${ }^{33}$ Id. Annex III. Various other activities of the United Nations on behalf of human rights are omitted from the present discussion. Such activities include among others, the work of the Sub-Commission on Freedom of Information and the Press; the Commission on the Status of Women; the Trusteeship System; the Sub-Commission on the Prevention of Discrimination and the Protection of Minorities, etc. For a brief survey see United Nations, For Fundamental Human Rights (x948), and current issues of United Nations Bulletin. See also Report of Fifth Session of the Commission on Human Rights, supra note 32.

${ }^{34}$ See U. N. Documents Nos. A/PV 179 (December 9, I948), and A/PV 183 (December xo, I948). There were no abstentions and none opposed to the Genocide Convention. A/PV I79 at 70. The Declaration was also unanimously approved, but with eight abstentions: Byelorussia, Czechoslovakia, Poland, Saudi Arabia, Ukraine, South Africa, Soviet Russia, Yugoslavia. A/PV 183, at I6r-165.

${ }^{a 5}$ Genocide Convention Art. II. See generally Comment, Genocide: A Commentary on the Convention, 58 YALE L. J. 1I42 (I949).
${ }^{30}$ Id. Art. II.
${ }^{37}$ Id. Art. IV.
${ }^{38}$ Id. Art. III.
${ }^{30}$ Id. Art. V.
${ }^{\circ}$ Id. Art. IX.
"I Id. Art. VIII.
${ }^{2}$ Id. Art. VI.
${ }^{3}$ See Report of the Commisston on Human Rights to the Economic and Social Council on 
nor is it designed to suppress a particular offense; it is a general expression of world policy as to civil and social rights, a policy of which the Genocide Convention is a striking application. It is a declaration of past achievement and future aspiration ${ }^{\mathbf{4}}$ and comprises the first step in the creation of an International Bill of Human Rights, a tripartite program to include ultimately conventions imposing international obligation for enforcement on both the domestic and international level. The product of compromise necessitated by wide divergence in economic resources available to fulfill its moral commitments ${ }^{45}$ and in emphasis with respect to relation between citizen and state, ${ }^{46}$ the Declaration provides for three basic types of rights: civil liberties and political rights; economic and social rights; and international rights. The first of these extends to personal liberties, including among others freedom and security of the person, freedom of thought, religion, assembly, etc., ${ }^{47}$ as well as the political right to participate in government on an equal basis; ${ }^{48}$ while the second category includes the right to social security, work, and choice of employment, and to education, leisure, and an adequate standard of living. ${ }^{40}$ The rights to nationality, freedom of transit, and political asylum comprise the third category. ${ }^{60}$ Limited as it is to moral suasion, the Declaration nevertheless occupies a powerful political position; it commands the attention of world public opinion.

Of more immediate importance from a legal point of view is the Covenant, presently in draft form for presentation to the Economic and Social Council. ${ }^{\text {t }}$ Like the Charter and the Genocide Convention it is conceived as a treaty committing signatories to specific obligations. Its substantive provisions, ${ }^{\text {62 }}$ for the most part the same as Articles 2-20 of the Declaration, ${ }^{53}$ extend to protection of life and liberty, ${ }^{54}$ against torture, mutilation, and slavery; ${ }^{55}$ of freedom of religion and thought, ${ }^{56}$ of speech, assembly, and association..$^{57}$ The alien is protected against arbitrary expulsion; ${ }^{58}$ and equal protection before the law, as well as with respect to all rights defined by the covenant, is accorded to all. ${ }^{50}$ Imprisonment for debt is prohibited, ${ }^{60}$ as are ex post facto laws ${ }^{61}$ and restrictions upon the movement of per-

the Second Session of tHE Commission, December 2-17, 1947, U. N. Doc. E/600, p. 19; Report of the Working Group, id. at 36,37 ; Comments by United Kingdom Representative, U. N. Doc. E/CN $4 / 82$ Add. 9, 1948, p. 2; see Hendrick, Progress Report on Human Rights, 19 Dep'T StATE Bull. 159, I60 (1948).

"See Preamble, supra note 31 .

"See Martin, The Universal Declaration of Human Rights, 3 World Affurs 292, 297 (1949).

${ }^{40}$ Id. at 296; see Malik, International Bill of Human Rights, 5 U. N. Bull. 5rg, 521 (1948).

47 The Declaration of Human Rights, Arts. 3-20.

${ }^{48}$ Id. Art. 21.

${ }^{80}$ Id. Arts. 13-15.

${ }^{51}$ See Rieport of the Commission on Human Rights, U. N. Doc., E/1371, stipra note 32. Both the draft Covenant and the proposals on implementation have been sent to member governments for comment, and are thereafter to be considered by the Economic and Social Council. Sec U. N. Doc., E/CN 4/I9I, 31 May, 1949.

${ }^{52}$ See Part II, Draft Covenant of Human Rights.

53 The exceptions are the right to privacy, asylum, nationality, and private property, Arts. 12, I4, 15, and $x 7$ of the Declaration.

Covenant Art. 5.

${ }^{57}$ Id. Arts. I7-ז9.

${ }^{85} I d$. Arts. 6,7 , and 8.

${ }^{50} I d$. Art. 16.

${ }^{\circ 0}$ Id. Art. to.

${ }^{8}$ Id. Art. 12.

${ }^{\circ 1}$ Id. Art. 14.
${ }^{80}$ Id. Art. 20. 
sons within a state. ${ }^{62}$ Particular emphasis is given the rights of the accused, both while under preliminary detention as well as in the course of subsequent trial. Such persons are accorded the right to a proceeding in the nature of a habeas corpus, notice of the charge, and a speedy termination of detention. ${ }^{63}$ There is explicit provision in the case of both civil and criminal offenses for a "fair and public trial," the right to counsel, confrontation by witnesses, compulsory attendance of witnesses, and, finally, for the right of presumed innocence. ${ }^{64}$ Signatories of this treaty-which has application to public officials and private individuals as well as to states ${ }^{65}$-would be obligated to make these provisions part of domestic law. ${ }^{66}$ Beyond this the means of enforcement as an international measure is still a subject of debate within the Commission on Human Rights. ${ }^{67}$ Whether the Covenant is intended to be selfexecuting remains at present in doubt also. ${ }^{68}$ In this respect, as in respect to the general war suspension clause ${ }^{69}$ and certain other provisions, ${ }^{70}$ the Covenant remains incomplete.

On the details of implementation the Commission has reached agreement on only one-an obvious-point, namely, that states shall be permitted to initiate complaints for enforcement, whatever the form of implementation finally adopted. ${ }^{71}$ In the fifth session in May-June, 1949, the right of petition by individuals, groups, or organizations was discussed but not agreed upon, the consensus being that further study

${ }^{02}$ Id. Art. Ix.

${ }^{\circ 3}$ Id. Art. 9.

${ }^{\circ}$ Id. Art. 13.

${ }^{00}$ Id. Art. 2.

${ }^{60}$ Ibid.

oz The Commission has barely broached its agenda on this subject. For discussions in the Fifth Session of the Commission (May-June 1949), see U. N. Documents E/CN $4 / S R ~ 105, E / \mathrm{CN}_{4} / \mathrm{SR}_{1} \mathrm{II}_{4}, \mathrm{E} / \mathrm{CN}_{4} / \mathrm{SR}$ $\mathrm{II}_{4}, \mathrm{E} / \mathrm{CN}_{4} / \mathrm{SR} \times I_{5}, \mathrm{E} / \mathrm{CN}_{4} / \mathrm{SR} \times 18, \mathrm{E} / \mathrm{CN}_{4} / \mathrm{SR} \times 19, \mathrm{E} / \mathrm{CN}_{4} / \mathrm{SR} \mathrm{r}_{32}, \mathrm{E} / \mathrm{CN}_{4} / \mathrm{r}_{33} ;$ also $\mathrm{E} / \mathrm{I}_{37} \mathrm{I}$ supra note 32.

${ }^{08}$ See Arts. 2 and 24. No definitive text for either article has been decided upon by the Commission, though Art. 2 has been provisionally adopted pending completion of Part II of the Covenant. The American proposal that Article 2 should contain language to the effect that "The provisions of this Covenant shall not themselves become effective as domestic law," was rejected by the Commission (see $\mathrm{E} / \mathrm{CN}_{4}$ /SR" 125, 22 June 1949). As it now stands paragraph I of the Article 2 reads: "Each state party hereto undertakes to ensure to all individuals within its jurisdiction the rights defined in this Covenant. Where not already provided by legislative or other measures, each State undertakes, in accordance with its constitutional processes and in accordance with the provisions of this Covenant, to adopt within a reasonable time such legislative or other measures to give effect to the rights defined in this Covenant." E/I371, p. 28.

${ }^{00}$ Art. 4 .

${ }^{70}$ Concerning Part I the Commission has decided to postpone consideration of the Preamble and Article I until the completion of Part II, or until, as in the case of Article 3, implementation measures are considered. Articles 2 and 4 have been provisionally adopted pending completion of Part II. Discussion of Article 17 in Part II has been postponed until the Sixth Session of the Commission, and Article 2 I until Article 17 is considered. Of Part III, only Article 23 dealing with ratification and accession has been completed. Numerous texts for the remaining three Articles are included in the Report of the Commission to the Economic and Social Council. See U. N. Document E/I37I, Annex I.

Even the substantive terms of Part II still seem in question. See Draft Resolution, under the heading "Draft International Covenant on Human Rights," submitted by the Commission to the Council, requesting information on U. N. activities involving economic and social rights (Articles 22-27 of the Declaration) "for the purpose of enabling the Commission to determine what actions it should take in these fields. ...." U. N. Document E/I37I Annex IV.

Art. 7 which deals with prohibitions against scientific and medical experimentation has been sent for comment to the World Health Organization. See E/r371, Annex III p. 30.

${ }^{71}$ U. N. Dac. E/CN $4 / S R$ Ir4-II5, E/I37I, p. I5. 
of the problem of handling such petitions was needed. ${ }^{72}$ As to the requisite type of enforcement machinery, extensive suggestions have been made, running between the extremes of conservative American-British and radical Australian proposals. The former, excluding individual petition by providing for reference to the International Court of Justice, ${ }^{73}$ envisages public protest and direct negotiation by a complaining state, in addition to hearings and investigation by a specially appointed United $\mathrm{Na}$ tions Committee. ${ }^{74}$ The latter calls for an International Court of Human Rights. ${ }^{75}$ At the request of the Commission, member governments are presently considering all alternatives of implementation, whether eventually to be effected through provision in the Covenant itself, ${ }^{\mathbf{7 6}}$ or by appended protocol, ${ }^{\mathbf{7 7}}$ or through a separate convention as originally intended..$^{78}$

It is regrettable that in terms of content the Covenant as presently drafted falls far short of the promise of the Declaration. It neither guarantees participation in government, the sine qua non of freedom, nor stipulates any aspirations about that economic well-being upon which today depends the fulfillment in fact of any human rights.

\section{III}

The principal attack from within the United States upon this program of the United Nations has come from certain leaders of the American Bar Association, notably President Holman and ex-President Rix. ${ }^{79}$ Though characterized more by

${ }^{72}$ U. N. Doc. E/CN 4 /SR II5, II8, II9, I32, I33; E/I37I, p. I9.

${ }^{73}$ Art. 34 of the Statute of the International Court of Justice provides: "1. Only states may be parties in cases before the Court." Dep't State Pub. No. 2368, Conference Series 76.

"See U. N. Doc. E/CN $4 / 274 /$ Rev. X, 3 I May r949; also the earlier Chinese-U. S. Proposal on Implementation which is substantially the same, though less detailed. E/CN $4 / 145$, I6 June 1948 .

${ }^{75} \mathrm{See} \mathrm{E} / \mathrm{CN}_{4} / \mathrm{AC} . \mathrm{I} / 27$, ro May $\mathrm{x} 948$; also $\mathrm{E} / \mathrm{I37}$, p. $6 \mathrm{r}$. Other suggestions have been put forward by France: E/CN $4 / 147,1948 ; \mathrm{E} / \mathrm{CN}_{4} / 82 /$ Add. 10, I948; E/CN $4 / 82 / A d d .10 / R$. I, 1949; $\mathrm{E} / \mathrm{I}_{37 \mathrm{I}}$ p. 70; by India: E/CN $4 / \mathrm{I}_{5} \mathrm{r}$ (amendment to Chinese-U. S. Proposals); E/CN $4 / \mathrm{I}_{53}$, $2 \mathrm{I}$ June 1948; E/I37r p. 77; by Guatemala: E/CN $/ 293, E /{ }_{37}$ 1 p. 75 . See also Report of Working Group on Implementation E/600 p. $33 \mathrm{et}$. seq. (Dec. 1947). The conclusion drawn by Russia relative to the various proposals is that they seek to engender systems of international pressurc; to interfere with the internal affairs of States in conflict with the "whole system of international public law"; and to transform disputes between individuals into disputes between States. For these reasons all the proposals are considered unsatisfactory. See USSR Statement, E/CN $4 / 154,24$ June 1948 ; also in E/r37r, p. 78.

${ }^{76}$ The current U. S, view. See $\mathrm{E} / \mathrm{CN}_{4} / \mathrm{SR}$ III.

гт lbid.

${ }^{78}$ See Malik, id. at 6.

${ }^{70}$ Holman, "An International Bill of Rights": Proposals Have Dangerous Implications for U. S., 34 A.B.A.J. 984 (I948), cited hereinafter as "Holman article," and President Holman's Comments on Mr. Moskowitz's Reply, 35 A.B.A.J. 228 (1949), cited hereinafter as "Holman reply"; Rix, Human Rights and International Law: Effect of the Covenant Under Our Constitution, 35 A.B.A.J. 55I (1949), cited hereinafter as "Rix" (first delivered as an address to the annual meeting of the American Socicty of International Law in Washington on April 29, 1949). For other references to the human rights program see Editorial, The Declaration and the Covenant, 35 A.B.A.J. 40-4I (1949); Report of the Committee for Peace and Law, presented to the House of Delegates of the American Bar Association, and comments thereon, 35 A.B.A.J. I96 (I949); Mr. Holman's remarks in "President's Page," 35 A.B.A.J. 201-202 (1949); Editorial, Wyman, Human Rights and the Declaration, 35 A.B.A.J. 406-408 (1949). Sce also Universal Human Rights, 34 Mass. L. Q. $45-84$ (1949).

The views expressed are uniform in their opposition to the program. The decision of the President and Board of Governors of the Association to promote a campaign of study of the proposals through regional meetings, study groups, and conferences-see 35 A.B.A.J. 40 (1949)--seems hardly to have evoked the enlightened discussion expected.

For answer to the bar leaders see Moskowitz, Is the U. N's Bill of Human Rights Dangerouts? A Reply to President Holman, 35 A.B.A.J. 283 (1949). 
rambling fulmination and quibbling questioning than by direct assertion which could be controverted, this attack may be said in reasonable summary to emphasize three main points. ${ }^{80}$ The first charge is that the United Nations program for human rights is an invasion of the domestic jurisdiction of the United States and other nations that has nothing to do with the maintenance of peace or any other matter of legitimate international concern. The second is that United States' participation in this program is unconstitutional and beyond the scope of the treaty or other federal power, since the program deals with matters more of state and local than of international or even national concern. The final charge is that United States' participation in the program is dangerously impolitic for a variety of reasons, the most important of which is that the program embodies an awesome threat to our free-enterprise system and form of government, stemming from economic reformers, professors, and Mrs. Roosevelt. ${ }^{81}$

The "domestic jurisdiction" charge is developed in various ways. Both $\mathrm{Mr}$. Holman ${ }^{82}$ and $\mathrm{Mr}$. Rix ${ }^{83}$ invoke Article 2, paragraph 7 of the United Nations Charter, which reads in part: "Nothing contained in the present Charter shall authorize the United Nations to intervene in matters which are essentially within the domestic jurisdiction of any state or shall require the Members to submit such matters to settlement under the present charter ..."84 To bring human rights within this reservation and exclude them from international concern, $\mathrm{Mr}$. Holman insists that "the whole purpose of the United Nations is to achieve peace" and that the maintenance of peace and preservation of human rights are separate problems, suggesting that neither of "the world wars were caused by the absence of an International Bill of Rights or primarily by subnormal or abnormal conditions in any country" and that at the time of launching these wars Germany "had the most advanced social and economic program of any nation in the world." 85 He insists further that the United Nations is primarily "an organization of states," operating "on an international level with government meeting government," while a "bill of rights, on the other hand, has nothing to do directly with the relations between governments; it exists primarily to define the relations between a government or state and the individual citizens thereof; basically it relates to internal affairs and not to international matters." the Bar Association Mr. Holman summarizes: "For the first time we have the proposals to take away from our people, their state and local government, and their

\footnotetext{
${ }^{80}$ If it be objected that our summary makes the bar leaders' attack too forthright, our query is then: what do they mean?

81 "We are dealing with a missionary spirit on the part of sacial and economic reformers to establish throughout the world their social and economic ideas. ..." Holman article, 985.

"She [Mrs. Roosevelt] and a few others, including Professor Jessup, have undertaken to bind the American people without their knowledge and consent." Holman reply, 290.

${ }^{82}$ Holman article, I080, 985 . ${ }^{83} \mathrm{Rix}, 618$.

sa The omitted words are: "but this principle shall not prejudice the application of enforcement measures under Chapter VII."

${ }^{85}$ Holman article, 985.
} 
national government as well, their control over the matters which have always been 'of domestic jurisdiction." "87 Mr. Rix's contribution to this point is to ride hard the nineteeth century canards that "international law is the law of states and their relations to each other, with all enforcement and negotiations in the states alone" and that it is inappropriate for international law to purport to concern itself with the relations between a nation-state and its citizens. ${ }^{88} \mathrm{He}$ asserts that the "reservation of domestic questions, known as Article 2 (7), is perfectly plain and concise" and that despite all the provisions in the United Nations Charter which call for "promoting, assisting, encouraging, recommending the cause of human rights," there has been no "creation of any contractual liability for recognition of human rights by any state." 89

The constitutional argument is more evasive, taking the form largely of vague questions. Thus, Mr. Rix inquires, quite irrelevantly to any question of constitutional power to secure human rights, "Is there no limit to the power of Congress acting under a treaty except that of prohibition in the Constitution," and, as if he were asking something new and unanswered, "Shall the treaty-making power be used as the basis for enactment of domestic legislation in the United States," and "What is the effect of treaty law as domestic law of the land, as supreme law under the Constitution." 90 Though he is nowhere explicit about limitations on the treaty power or other federal power over foreign affairs, Mr. Rix quotes with approval the well-known address of Chief Justice Hughes which distinguishes agreements relating to "the conduct of our international relations" from those which do not "pertain to our external relations" but rather to matters "normally and appropriately" within "the local jurisdictions of the states," and assumes, without halting for reflection on the question of fact, that "the wise words of Chief Justice Hughes" give sufficient answer to the question whether the treaty-making power shall be used as the basis for enactment of domestic legislation on human rights. ${ }^{91}$ Referring to a suggestion of the President's Committee on Civil Rights that the treaty-making power might be so used, he finds that the "road to federal absolutism, is being made very, very easy." Mis Missouri v. Holland, ${ }^{93}$ in which Justice Holmes delivered his famous and statesmanlike opinion on the scope of the treaty power, is described as the case "in which Leviathan, with deep concern for the food supply of wild duck for a suffering people, blithely asserted that there is no limit in the United States to the treatymaking power and legislation enacted thereon unless it is prohibited by the Constitution." "94 Fearing the "destruction of a cherished system of our division of powers of government, ${ }^{, 95} \mathrm{Mr}$. Rix has this to say of the potentialities of the Genocide Convention and of the proposed Covenant on Human Rights: ". . . there may be created,

${ }^{87}$ Comment by Mr. Holman before the House of Delegates of the American Bar Association, January 3I, 1949. See 35 A.B.A.J. 196 (1949).
${ }^{88} \operatorname{Rix}, 552$.
${ }^{80} I d$. at $6 \mathrm{r} 8$.
${ }^{01} \mathrm{Id}$. at 554,618 .
${ }^{02} \mathrm{Id}$. at $6 \mathrm{I} 8$.
${ }^{00} I d$. at 552.
${ }^{\circ} I d$. at 554 .
${ }^{25} I d$. at 552 .

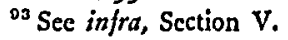


as law, a third body of treaty law in this country with no constitutional basis whatsoever, of equal dignity with the Constitution, as supreme law of the land, superseding all state constitutions, decisions and laws of the states covering the same subjects, and probably superior to all prior enacted laws of Congress on the subject." The consequences of this "in a field which has been almost exclusive [sic] in the states, is so far-reaching . . . that the word revolutionary is not fully descriptive." Mr. Holman also thinks this "dangerous." "Ts "The problem is considered aggravated by Supreme Court decisions dealing with centralization of federal power, by the recent restrictive covenant cases, and by the lack of uniformity in state anti-discriminatory employment legislation. With respect to restrictive covenants Mr. Holman urges, despite the Supreme Court ruling that they are not enforceable, that "the United States should not subscribe to setting aside what has been long established and recognized as a proper restriction with respect at least to limited areas of property." In any event Mr. Holman, apparently hopeful, suggests these cases may be overruled. ${ }^{100}$ A minor constitutional theme, much emphasized, is that in international undertakings of this kind this country is peculiarly vulnerable since, in contrast with the further action required in most countries, under Article VI (2) of our Constitution self-executing treaties upon ratification immediately become the law of the land-apparently irrevocably, since "this country is not in the habit of ratifying treaties with the intention of repudiation."101

The final charge that the human rights program is dangerously impolitic for the United States is made explicit enough. Its general tenor, repeated over and over, is that the provisions of the Declaration and proposed Covenant in so far as they are traditional are vague and unnecessary and likely to expose us to a "Pandora's box of complaints" from within and without, and in so far as they are not traditional are long steps toward "world-wide socialism," if not communism. ${ }^{102}$ Thus, in strong isolationist vein $\mathrm{Mr}$. Holman asserts that we risk "many international irritations and provocations" from "United Nations intervention in the domestic affairs of nations."103 If, he develops his theme, "the United Nations, through its own interpretation, is the final arbiter of what constitutes a matter of international concern then by its ipse dixit, the acts of our citizens, our courts and our public officials will be amenable to examination and condemnation and eventual control by the United Nations."104 Worse still, "both individuals and pressure groups in other countries, even in Russia, could have a Roman holiday in asking American cities and states, and even our federal Government, for extended explanations regarding the observance and protection by them of so-called human rights with respect to our own citizens."105 "I leave to your imagination," states Mr. Rix, "as to what would

${ }^{\circ 0} \mathrm{Id}$. at 554 .

${ }^{08}$ Holman article, I08I.

200 Ibid.

${ }^{\text {or }}$ Ibid.

${ }^{90}$ Id. at ro79.

${ }^{101}$ Rix, 554. See also, Holman reply, 360.

${ }^{103}$ Holman article, 1080, 985. Holman reply, 290.

${ }^{203}$ Holman article, 985.

${ }^{100} I d$. at $36 \mathrm{r}$. 
happen in the field of administration of municipal law if subversive elements should teach minorities that the field of civil rights and laws had been removed to the field of international law. ..."106 The introduction of the principle of individual as against state responsibility into international law will inevitably create "correlative rights and privileges .... to an utterly unknown degree."107 The charge that the program will promote "state socialism, if not communism, throughout the world"108 is supported by allegations that it will foster "economic and social boons, bounties and benefits" which encourage a "planned economy or welfare state,"100 that it is "paternalistic" and "minimizes the incentive for initiative and progress,"110 and that it emphasizes "rights" but not "responsibility."111 From a view, as parochial as unrealistic, it is urged that foreign standards of human rights (impliedly, without qualification, inferior to ours) will be enforced against us to the detriment of our own Bill of Rights; and, conversely, that while human rights in the United States are God-given and inalienable, peoples abroad are not so endowed and should not have human rights imposed on them. ${ }^{112}$ One crowning non-sequitur is the argument that omission from the Covenant of any right deemed essential, the right to own property for instance (a right included in the Declaration), automatically limits the exercise of that right in the United States. ${ }^{113}$ A prominent and recurrent emphasis is that we must go slow, that international law is not made "in the twinkling of an eye," that it is better to await the "evolutionary process of building customary law" and not use that prime instrument of international legislation, agreement, or treaty, which is described as "summary process."114

\section{IV}

The recital in Article 2(7) of the United Nations Charter that "nothing contained in the present Charter shall authorize the United Nations to intervene in matters which are essentially within the domestic jurisdiction of any state or shall require the Members to submit such matters to settlement under the present charter" is, despite the contrary allegations of the bar leaders, utterly irrelevant to any issues posed for either the United States or any other nation-state by the proposed Covenant on Human Rights and the Genocide Convention. This limitation in the Charter, whatever meaning may eventually be ascribed to it or whoever may eventually be decided to have power to interpret $i{ }^{115}$ is a limitation only on the organization set

${ }^{100} \mathrm{Rix}, 554 . \quad{ }^{108} \mathrm{Rix}, 554 . \quad{ }^{108}$ Holman article, 1080.

${ }^{100}$ Report of the Committee on Peace and Law, 35 A.B.A.J. I96 (1949).

${ }^{110}$ Holman article, 1080 .

${ }^{111}$ Wyman, Human Rights and the Declaration, 35 A. B. A. J. 406, 408 (1949).

112 Remarks of Mr. George A. Finch at the 1949 meeting of the Amercian Society of International Law, which will appear in the 1949 Proceedings of the Society. See also Wyman, supra note 11 1 , at 407. ${ }^{113}$ Holman article, 986.

-115 For a brief indication of the variety of opinion on these points see LELAND M. Goodricil AND Edvard Hambro, Charter of the United Nations: Commentary and Documents ilo et seg. (rev. ed. r949).

Among the more useful discussions of Article 2(7), putting it in proper perspective, are Goodrich, The United Nations and Domestic Jurisdiction, 3 Int. ORG. I4 (1949); Fincham, Domesnc Jurisdiction (1948); Gross, Impact of the United Nations upon Domestic Jurisdiction, I 8 DEP'T STATE BuLl. 259 (1948); Comment, 47 Cor. L. Rev. 268 (1947). 
up by the Charter and upon activities which depend upon the Charter for their constitutional base. ${ }^{116}$ The proposed Covenant on Human Rights and the Genocide Convention are to be new agreements, stemming from the same nation-state power, "the competence attached to sovereignty,"117 that established the United Nations Charter and which remains competent to clarify or supplement the obligations assumed in that Charter to promote respect for and observance of human rights. There is nothing in the United Nations Charter or in any other international agreement or in customary international law which derogates in the slightest degree from the power and competence of the members of the United Nations to make further agreements about human rights and to establish common standards, to whatever extent desired, about practices within their respective jurisdictions, "domestic" or otherwise. ${ }^{118}$ The obvious and fundamental principle of customary law is well stated by Sir Arnold McNair: ". . . international law regards a State as being invested for international purposes with complete power-vis-dे-vis another contracting party-to alienate or otherwise affect the rights of its nationals, both property and personal, and to impose liabilities upon them."119 More affirmatively, it is uniformly

110 The assurances, therefore, of Mr. Stetinius that domestic questions were reserved at San Franciscoassurances upon which Mr. Rix heavily relies (see Rix, 6r8)-are irrelevant in so far as the substance of the Covenant and the Genocide Convention is concerned. Referring to the enlargement of the scope of Art. 2, paragraph 7, to cover "activities of the organization as a whole, instead of limiting it to the pacific settlement of disputes as had been proposed at Dumbarton Oaks," Mr. Stettinius stated that "the possibility is now definitely excluded" that "the Economic and Social Council could interfere directly in the domestic economy, social structure, or cultural or educational arrangements of the member States." Report to the President on the Results of the San Francisco Conference, Hearings before the Senate Committee on Foreign Relations, 79th Cong., Ist Sess. 58 (1945).

Compare the official remarks of Committee II/3 at San Francisco relating to the objectives of the Economic and Social Council:

"There were some misgivings that the statement of purposes now recommended implied that the Organization might interfere in the domestic affairs of member countries. To remove all possible doubt, the Committee agreed to include in its records the following statement:

"The members of Committee 3 of Commission II are are in full agreement that nothing contained in Chapter IX [International Economic and Social Cooperation] can be construed as giving authority to the Organization to intervene in the domestic affairs of member States.' (Italics supplied.)

"The Committee agreed that it was desirable to reinforce the statement of purposes by a pledge on the part of individzal members. The precise wording of the pledge was extensively debated and the form finally agreed upon reads as follows:

'All members pledge themselves to take joint and separate action in cooperation with the Organization for the achievement of these purposes." " 8 Documents of THE UNITED Nations Conference on International Organization, San Frantisco, ig45 8x-82 (1945). (Italics supplied.)

See also the decision that it is for the Organization to "promote" human rights, but for the States to "protect" them, except where "rights and freedoms are grievously outraged so as to create conditions which threaten peace or to obstruct the application of provisions of the Charter," when they cease to be the sole concern of each State. 6 id. at 705 .

${ }^{217}$ The phrase is Oppenheim's. I L. F. L. Oppenheim, International Law 795 (Lauterpacht ed. 1948 ).

${ }_{218}$ The general point is well developed by Charles Fahy, then Legal Adviser of the Department of State, in discussing comparable problems raised by the International Trade Organization Charter in Hearings before the Senate Committee on Finance, Part I, 8oth Cong., Ist. Sess. (1947).

${ }^{210}$ arnold D. McNarr, The Law of Treaties 335 (1938). Cf. Oppenheim, op. cit. supra note iI7, 
established by authority as high as the Permanent Court of International Justice that nation-states may by agreement take matters, such as nationality, out of what might otherwise be regarded as "domestic jurisdiction" and make them of international concern and subject to international regulation. ${ }^{120}$ If, finally, the inspiring words, so many times repeated, of the United Nations Charter are not to be taken as sheer mockery and humbuggery of the peoples of the world, that Charter itself, with its clear statement of major purpose and several undertakings, must be construed, not as precluding member states from further concern and agreement about human rights, but rather as obligating them to such action.

It cannot in fact be disguised, by any amount of reverent invocation of irrelevant technicalities, that the real issue posed for the United States, as for every other nation-state, is the policy issue: whether it should enter into new agreements of the type proposed. ${ }^{121}$ The critical question in simplest terms is whether or not the human rights and security, in the sense of freedom to pursue all values by democratic procedures, of the people of the United States, and of any other peoples with whom they identify, are sufficiently at stake to justify the United States in assuming obligations of the kind proposed in return for other nation-states assuming reciprocal obligations. Rational answer to this question depends, not upon exercises in

at 804. Potter, Inhibitions Upon the Treaty-Making Power of the United States, 28 AM. J. INT'L L. 456, 463 (1934) writes:

“. . . international law bestows a plenary power of concluding treatics upon cvery State. A priori, and in the absence of any valid restrictions of a special nature arising from either national or international sources, the power of the United States and of its treatymaking agency to conclude agreements with other states which are mutually acceptable to both is unlimited, in terms of either subject matter or of type of treatment for that subject matter to be provided in the agreement, assuming freedom from the exercise of force or fraud upon the negotiators at the time of concluding the treaty. Such plenary power continues to accompany, or stand back of, and possibly exceed, the degree of treaty-making power purporting to be granted by the national constitution. The making of treaties by the states antedated the formation of modern international law, and the latter emerged as a result of that process, but today it is international law which sustains trcaty-making, and that in plenary degree."

120 Tunis-Morocco Nationality Decrees, Permanent Court of International Justice, r923, Publications of the Court, Ser. B, No. 4 (Advisory Opinon) (1923); see also German Settlers in Poland, P.C.I.J., Ser. B, No. 7, p. 16 (1923); Case Concerning Certain German Interests in Upper Silcsia, P.C.I.J., Scr. A, No. 6, pp. 14, I5 (1925); Treatment of Polish Nationals ... in Danzig Territory, P.C.I.J. Ser. A1 B, No. 44, p. 42. Cf. Philip C. Jessup, A Modern Law of Nations 87 (1948).

${ }^{121}$ This is the issue even if one assumes, as the bar leaders insist, that Article 2(7) of the United Nations Charter is relevant and that for the purposes of that Article the United States is the exclusive judge of what is within its domestic jurisdiction. The United States must still determine what it will consider within its domestic jurisdiction.

With the bar leaders' horror of the suggestion that the interpretation of Article 2(7) may be a mattcr of international concern, may be contrasted Judge Hudson's strictures on this same article in The World Court: America's Declaration Accepting Jurisdiction, 32 A.B.A.J. 832, 835 (1932): "This text marks a distinct retrogression. Unlike that in the Covenant, and unlike the previous Declarations accepting the Permanent Court's jurisdiction, it provides no competent forum for the determination of the question whether a matter is essentially within the domestic jurisdiction of any statc."

The insight and vision of earlier bar leaders with respect to the comparable problem of the jurisdiction of the International Court are indicated in Hudson, stipra; Preuss, Questions Restlting from the Connally Amendment, 32 A.B.A.J. 66o (1946), and Jurisdiction of World Court: Reasons for Urging $a$ New American Declaration, 33 A.B.A.J. 430 (1947); Withdrawal of Connally Amendment as to the World Court is Urged, 34 A.B.A.J. I86, 256 (1948). 
authoritative doctrine, but upon correct orientation in realm of fact-in the realm of present degrees of, and probable future trends in, interdependence among the peoples of the world with respect to human rights and security. Mr. Holman's insistence upon the separateness of the problems of human rights and peace, with documentation by reference to the course of Nazi Germany, suggests a very considerable disorientation. Because of the demands, conditions, and trends indicated in the introductory paragraphs of this article, we prefer to take our stand with the great bulk of mankind-witness the general consciousness pervading not only the declarations of war aims and the framing of the United Nations organization and its subsidiaries, but also the subsequent pronouncements and practices of the United Nations agencies and the late frantic scrambling for regional pacts and associationswho see both a general, irrevocable interdependence of all peoples everywhere as to all values and a specific connection between the internal tyranny of nation-states and their external aggression. ${ }^{122}$

For resolution of the issue of policy thus posed for the United States and other nation-states, one fact at least is certain: there is nothing in the technical concept "domestic jurisdiction," whether considered generally or as put forward in the United Nations Charter, that offers any guidance. The words "domestic jurisdiction" are neither possessed of any intrinsic or absolute meaning nor are they selfdefining. ${ }^{123}$ Neither official pronouncement nor practice of states has ever given them a very precise meaning for any purpose, much less of relevance to rational action about human rights in the contemporary world. ${ }^{\mathbf{1 2 4}}$ Introduced into the Covenant of the League of Nations on the suggestion of American statesmen in the vain hope of appeasing isolationist sentiment, this "mischievous phrase" has, in the apt description of a distinguished critic, ${ }^{125}$ become a "new catchword" or verbal "idol" to serve the same old function that words like "sovereignty," "independence," and "state equality" have so long served. That function is much too often to put a stop to thought, to summarize conclusions reached on unexpressed or perhaps even unexamined or unconscious grounds, and to assert arbitrary refusal to negotiate or cooperate on problems regarded by other states as of common concern. When definition is proffered by disinterested authority, it is invariably cast in terms of relativity. ${ }^{126}$ Thus, the Permanent Court in a much quoted passage asserted: "The question whether a certain matter is or is not solely within the jurisdiction of a state is essentially a relative question; it depends upon the development of inter-

\footnotetext{
${ }^{122}$ It surely cannot be seriously suggested that Russia's systematic exclusions from access to political power, repression of all opposition, and iron-curtain policy with respect to enlightenment have no bearing on her foreign policy or her peoples' willingness to accept that policy:

${ }^{123}$ Cf. Preuss, The International Court of Justice, 40 AM. J. INT'L L. 720, 726 (1946).

124 Fincham, op. cit. supra note 115 , offers complete review.

${ }^{125}$ Professor James L. Brierly. His early article, from which the quotations are taken, 6 BRIT. Y. B. INr'L L. 8 (1925), is still the most incisive analysis. For later developments see Bentwich, The Limits of the Domestic Jurisdiction of the State, 3I TR. OF Grotnus Society 59 (1945); Davies, Domestic Jurisdiction, 32 Tr. of Grotrus Socretr 60 (1946).

${ }^{220}$ Fincham, op. cit. supra note 115 , at 40 .
} 
national relations." ${ }^{127}$ Such definition obviously merely restates the question of the facts about world-wide interdependence. It may be instructive to note that in all the discussion that attended the framing of Article 2(7) of the United Nations Charter very little effort was devoted to clarifying the meaning of the limitation proposed for the organization. The record of San Francisco reveals (I) a design to extend the scope of paragraph 7 (limited in Dumbarton Oaks to the pacific settlement of disputes) to all the organs and activities of the United Nations, (2) a considerable diversity of opinion as to who should interpret the paragraph, (3) a belief that "essentially" is broader than the League word "solely," and (4) some notion that traditional international law is too vague and antiquated to assist in definition; but there is practically no discussion of what in substance constitutes "matters essentially within the domestic jurisdiction of any state."128 There is evidence indeed of deliberate intent to postpone clarification for the future development of practice. Thus, Mr. Dulles for the United States, in rejecting the standard of international law, "pointed out that international law was subject to constant change and therefore escaped definition," and insisted that "it would, in any case, be difficult to define whether or not a given situation came within the domestic jurisdiction of a state." "In this era," the official paraphrase continues, "the whole internal life of a country was affected by foreign conditions." The record reads: $:^{130}$

In summary, Mr. Dulles stressed the virtues of the principal-its breadth and its simplicity. The Organization in none of its branches or organs should intervene in what was essentially the domestic life of the member states. Moreover, this principle was subject to evolution. The United States had had long experience in dealing with a parallel problem, i.e., the relationship between the forty-eight states and the Federal Government. Today, the Federal Government of the United States exercised an authority undreamed of when the Constitution was formed, and the people of the United States were grateful for the simple conceptions contained in their Constitution. In like manner, Mr. Dulles foresaw that if the Charter contained simple and broad principles future generations would be thankful to the men at San Francisco who had drafted it.

When Mr. Dulles had concluded, "the Chairman moved a vote of thanks" for "his masterly exposition" and "Mr. Evatt rose to second this motion." Clearly "domestic jurisdiction" still awaits content from the realities of the contemporary world power process.

Equally unenlightening for rational policy decision by the United States or others is the doctrinal half-truth, paraded by the bar leaders, that traditional international law concerns itself only with states and not with individuals. Even if it were a fact that traditional doctrines designed to regulate relations between nation-states in

\footnotetext{
127 Tunis-Morocco Nationality Decrees, stipra note 120 .

${ }^{128}$ Fincham, op. cit. supra note 115 , at 147 . See 6 Documents of the United Nations Conference on International Organization, San Francisco 507-513, iro-iil (I945); also Report to thie PrestDENT, supra note II6, at $26,57-58$.

${ }^{129} 6$ DocumeNTs, supra note 128 , at $508 . \quad{ }^{130} \mathrm{Ibid}$.
} 
"an unscientific age of subsidized piracy, matchlocks, wood fires and candlelight, wide-open spaces, and glorification of cruel aggressive force for selfish profit"131 were not designed and did little to protect the individual human being, that fact would be of little relevance to the task of defining doctrine and creating institutions appropriate for protecting the individual human being in this atomic era. It is not questioned of course that in recent centuries nation-states have been the principal participants in the world power process and that by reason of habitual anthropomorphic reification such states have been made the principal addressees of the doctrines of international law. The fact is, however, despite all the hair-splitting about the "subjects" and "objects" of international law, the ultimate beneficiary of its doctrines has always been the individual. In eloquent castigation of the reiterated view that international law "is a law between states" under which "individuals have no rights and no personality," Professor Frederick Dunn states:.132 "In my view, this particular legal fossil is highly misleading and in large degree false, and its continued hold on the minds of many people explains in part why international law is held in such ill repute by laymen today." Referring to the common rule that international law is part of the law of the land, Lauterpacht praises the rule as "an beneficent doctrine inasmuch as it brings into prominence the fact that the obligations of international law are, in the last resort, addressed to individual human beings."133 Often quoted is the wisdom of Westlake: "the duties and rights of states are only the duties and rights of the men who compose them."134 Emphasis upon the theoretical relation of "states" to the exclusion of individuals is in fact of relatively recent origin, a product of nineteenth century positivism. ${ }^{135}$ The law of nations of previous centuries with its roots in natural law, both Christian ${ }^{136}$ and Greek, and in the jus gentium of the Roman world, gave a primary place to the individual, the very essence of natural law being that sense of moral justice, of "right reason," which has no meaning except in terms of a heightened awareness of the worth of human personality. ${ }^{137}$ Even the most casual glance at the works of Grotius and Pufendorf-or even Vattel-demonstrates the tremendous impact of this idea. Clearly it was a principal consideration in the efforts of Grotius, the accepted father of international law, to restore order to the troubled world of the seventeenth century. It is indeed only from the narrowest perspectives of international law as conceived

\footnotetext{
${ }^{231}$ Borrowed from Bingham, The Continental Shelf and the Marginal Belt, 40 AM. J. INT'k L. I73, 178 (1946).

${ }^{132}$ Dunn, The International Rights of Individuals, Proc. Am. Soc. INT'L L. 14 (194r). Cf. Brown, World Law, 40 AM. J. Int'l L. I59 (1946); Chardes G. Fenwick, International Law i34 (3d ed. I948).

${ }^{133}$ OpPENHEIM, op. cit. supra note $\mathrm{II} 7$, at $2 \mathrm{I}, 4 \mathrm{I}$.

134 John Westlake, Collected Papers on Public International Law 78 (1914).

${ }^{135}$ Idelson, The Law of Nations and the Individual, 30 Tr. OF Grotius Society 50 (1944).

${ }^{130}$ For an enlargement of this orientation of Human Rights, see Jaceues Maritain, The Rights of Man and Naturar Law (1943).

${ }^{132}$ Idelson, stupra note 135 , at $5 \mathrm{x}$; Report of Lord Porter's Committee on "International Law and the Rights of the Individual," 31 Tr. OF Grotrus Society 90 (1946).
} 
in the period since Bentham that an observer can claim that even theoretically only states, exclusive of individuals, are the subjects of international law. Apart from theoretical considerations, nineteenth century international law, oriented as it was to utilitarianism and laissez-faire, has in fact promoted the interests of individuals rather than bare relations between sovereign states. This is the import of rules regarding the diplomatic protection of citizens abroad, of the laws of war and of neutrality, and of many of the doctrines about jurisdiction. ${ }^{138}$ One has, furthermore, only to look at the content of treaty-law to gain true perspective as to the preponderance of concern for the activities of men over the inter-relations of states. ${ }^{130}$ Treaty-law reveals also the beginning of a trend toward an increased role for the individual in the procedural aspects of international law. Witness the granting of the right of individual access to international tribunals, such as the Central American Court of Justice, or the Arbitral Tribunals set up after the first World War. ${ }^{140}$ In more recent years the myth that nation-states are the sole subjects of international law has received other fatal blows from the demands of a whole host of organizations-such as the United Nations itself, the Bank, the Fund, and UNRRA-for "personality" and all of its attendant rights and privileges in international doctrine and practice. ${ }^{141}$ It is coming more and more to be recognized that nation-states, as important as they are, are not the sole participants in the world power process, and that the most critical challenge of our time is the task of devising a world law appropriate for all the new participants, such as international governmental organizations, transnational political parties, transnational private associations (cartels), and even the humble individual human being. ${ }^{142}$

Similarly without enlightenment and relevance to wise policy decision about the human rights agreements is that other, complementary half-truth, invoked by the bar leaders, that by traditional international law there can be no interference from any source in the relations between a nation-state and its citizens. Even if it be assumed that by customary international doctrine nation-states have been left largely free to treat their own citizens as they will, the conclusion that such states cannot agree, or that it is unwise for them to agree, to do otherwise is a transparent and arrogant non-sequitur. As the American Bar Association's thoroughly considered monograph, The International Law of the Future, recites with documentation: "In-

\footnotetext{
${ }^{138}$ Dunn, supra note 132 , at 15 .

${ }^{130}$ It may be emphasized that all agreements which become the law of the land have very dircet effects on the citizens of a state.

${ }^{140}$ Hambro, Individuals before International Tribunals, Proc. AM. Soc. INT'L L. 28 (194I); PunLp C. Jessup, A MOdern Law of Nations 18 -19 (1948); Idelson, supra note 135 , at 60; Aufricht, Personality in International Law, 37 AM. PoL. Scr. Rev. 217 (1943).

${ }^{14 I}$ See International Court of Justice Reparations for Injuries Suffered in the Scrvice of the United Nations, Advisory Opinion: INTERnational CouRT of JUSTICE Reports 174 (1949); Reparation for Injuries Suffered in the Service of the United Nations, oral statements by Kerno and Feller, Uniterl Nations (1949). Jenks, The Legal Personality of International Organizations, 22 BRIT. Y. B. INT'L L. I I (1945); see also Idelson, stipra note 135 , at 59 and citations therein.

${ }_{142}$ This is a principal theme of Philip C. Jessup, A Modern LAw of NAtrons (1948), generally recognized as the most profound of contemporary books on its subject.
} 
stances are numerous in which states have assumed obligations with respect to the treatment of their own nationals."143 Wholly apart from agreement, states have long assumed a prerogative of humanitarian intervention "when a State renders itself guilty of cruelties against and persecution of its Nationals, in such a way as to deny their fundamental human rights and to shock the conscience of mankind."144 Drawing upon a variety of precedents, such as "long prescribed standards for a State's protection of aliens within its territory," and insisting that "nationals too should have the benefit of the standard which the dictates of humanity and justice impose," the American Bar Association monograph, mentioned above, generalizes in Principle 2: "Each State has a legal duty to see that conditions prevailing within its own territory do not menace international peace and order, and to this end it must treat its own population in a way which will not violate the dictates of humanity and justice or shock the conscience of mankind."145 Comment explains that this "Principle would require of each State a minimum protection" of "all inhabitants of its territory." 4 A very recent precedent of world-wide renown and of potentially tremendous influence may be found in the Nuremberg Charter and Judgment. ${ }^{147}$ Though principally acclaimed for its imposition of duties upon the individual irrespective of nation-state law, the Nuremberg precedent makes positive contribution to the international protection of human rights. Along with crimes against peace and war crimes, Article 6 of the Charter lists crimes against humanity: "Namely, murder, extermination, enslavement, deportation, and other inhumane acts committed against any civilian population, before or during the war, or persecution on political, racial or religious grounds in execution of or in connection with any crime within the jurisdiction of the Tribunal, whether or not in violation of the domestic law of the country where perpetrated." Though limited by the judgment of the Tribunal to "inhumane acts, in connection with the planning or waging of aggressive war," 148 this concept of crimes against humanity is capable of future generalization. The significance of the precedent is best stated by Professor Lauterpacht:

... Crimes against humanity are crimes regardless of whether they were committed in accordance with and in obedience to the national law of the accused. Such acts

243 American Bar Association Journal, The Internattonal Law of the Future 36 (1944). A foreword indicates that the monograph is a product of some thirty regional conferences, inspired and led by Judge Hudson. Cf. Jessup, op. cit. supra note 142 , at 88 .

14 Oppenheim, op. cit. supra note II7, at 280. Cf. I Charles C. Hyde, International Law 249, 209 ( 2 d cd. 1945) offering (at p. 2rr) prophetic understatement: "It is to be expected that international society will ultimately evince an interest in the welfare of the private individual sufficient to cause the law of nations to restrict the freedom of a State in the treatment of its nationals."

${ }_{145}$ Stupra note 143 , at $35-37$.

${ }^{147}$ An excellent brief summary appears in International Law Commission, United Nations, The Charter and Judgaient of the Nuremberg Tribunal (I949).

Other contemporary rejections of the "act of state" doctrine also demonstrate that the relation between a state and its own citizens is not the sacrosanct citadel that some mythology suggests, Comment, 57 YaLE L. J. 108 (1947). Note especially the acts of allied military government in setting aside Nazi expropriations. If it is possible to act after the fact to make amends, how much more rational to act before the event to prevent inhumanities from occurring.

${ }^{248}$ International Law Commission, op. cit. stupra note 147 , at 68. 
were deemed to violate the sanctity of human personality to such a degree as to make irrelevant reliance upon the law of the State which ordered them. To lay down that crimes against humanity are punishable is, therefore, to assert the existence of rights of man grounded in a law superior to the law of the State. Thus, upon analysis, the enactment of crimes against humanity in an international instrument signifies the acknowledgment of fundamental rights of the individual recognised by international law. ${ }^{140}$

The power of agreement to vary customary doctrine and impose special obligations upon states in the treatment of their own citizens has, as the Bar Association monograph suggests, been many times demonstrated. Among the better known examples are the "minorities treaties" after World War I for the protection of racial, linguistic, and religious groups, and the more general provisions in the peace treaties concluded since World War II, examples which are being developed in other parts of this symposium. . ${ }^{150}$ Mention might also be made of "an imposing array"161 of agreements for repressing slavery and the slave trade, for promoting humane conditions of labor, for preventing white-slavery, for policing opium trade, for protecting aborigines, for safeguarding health, and so on. ${ }^{152}$ The agreement we should like most to emphasize is, however, the United Nations Charter itself. It is simple anachronism to suggest that the proposed Human Rights Covenant and the Genocide Convention embody revolutionary innovation. Whatever innovation there is, the decisive break with all past unconcern of customary international law for human rights, the generalization of all the many precedents indicated above into a principle of positive concern, came with adoption of the Charter four years ago. "It is already law," writes Ambassador Jessup in contrast to Mr. Rix, "at least for Members of the United Nations, that respect for human dignity and fundamental human right is obligatory. The duty is imposed by the Charter, a treaty to which they are parties."153

${ }^{140}$ Lauterpacht, The Subjects of the Law of Nations, 64 L. Q. Riev. 97, ro4 (1948). See also UNITED Natrons War Crimes Commission, History of the United Natjons War Crimes Commission 174,192 (1948); Brand, Crimes Against Humanity and the Nuremberg Trials, 28 ORE. L. Rev. II9 (I949); Lowenthal, Harris, Woolsey, and Farr, The Nuremberg Verdict, 60 HaRv. L. Rev. 857, 884 (1947).

${ }^{150}$ Articles by Mary G. Jones and Stephen Kertesz, infra.

${ }^{181}$ Borrowed from OPPENHEIM, op. cit. stipra note 117 , at 584 .

${ }^{252}$ Quincy Wright, Human Rights aNd Wordd Order 15 (Commission to Study the Organization of Peace, I942).

For international control of atomic energy the United States has proposed a system of inspection which would invade the relations between a state and its citizens, and few observers outside the Soviet Union doubt that such a measure is necessary to adequate enforcement of security. Sec Sults, THe Atomic Bomb in Wordo Politics (i948); International Control of Atomic Energy, Growti of a Policy (U. S. Dep't State, 1946), and Policy AT THE Crossrosds (1948).

The important point is not whether a proposed agreement interferes in the relations between a state and its citizens, but whether the objectives of the parties, considering the whole context in which they find themselves, require such interference. If it is necessary to the adequate protection of human rights and to security to require states to assume obligations with respect to their own citizens, such action is no less rational and no more contrary to international law than the proposed inspection system for atomic energy.

${ }^{153}$ Jessup, op. cit. supra note $142,26,9 \mathrm{I}$.

For clarity of thinking it is necessary to observe a distinction between binding obligation as between nations under international law and the internal or domestic effects of an agreement as a "part of the law of the land." To establish binding international obligation it is not necessary to establish that the terms of the United Nations Charter are sufficiently precise and "self-executing" to become the law 
Similarly, Professor Lauterpacht insists that the human rights provisions of the Charter are not "mere embellishment of an historic document"154 but rather constitute binding legal obligation, recognizing "fundamental rights of the individual independent of the law of his state." "The Charter of the United Nations is," he writes, "a legal document; its language is the language of law, of international law. In affirming repeatedly the 'fundamental human rights' of the individual, it must of necessity be deemed to refer to legal rights-to legal rights recognized by international law and independent of the law of the State."155 It is, therefore, the task and opportunity of the proposed new agreements, not to innovate in principle, but to translate obligation already assumed into concrete detail in the practice of states.

Though irrelevant to establishing the unimpaired power of nation-states to make new agreements about human rights, the practice of the various organs of the United Nations under the Charter during the past four years is relevant as evidence of the common consensus of mankind that all peoples everywhere are interdependent as to human rights and security. ${ }^{156}$ Contrary to the broad interpretation favored

of the land, without further legislative implementation. What agreements, in the absence of a clear expression of intent, are or are not "self-executing" under our law is still a matter of speculation and controversy. Dickinson, Are the Liquor Treaties Self-Exectuing, 20 AM. J. INT'L L. 444 (1926); Henry, When Is a Treaty Self-Executing, 27 Mrch. L. Rev. 776 (1929). It may be observed, however, that a promise to promote respect for and observance of human rights and freedom is not, under common sense interpretation, compatible with insistence upon the maintenance of internal doctrines and practices destructive of human rights and freedom and violent opposition to all change. The declarations of the framers of the Charter at San Francisco are, moreover, instructive. On the necessity for including the maintenance of human rights under the Charter, the official record states:

"There was considerable discussion . . . of this point, with emphasis on the idea that respect for human rights should also be mentioned in Chapter II ["Principles," now Chapter I] as a principle to be observed by all members. It was felt that if this statement were included only in Chapter I ["Purposes," now Chapter I], it would bind only the Organization and would relieve member governments from the obligation to respect the fundamental freedoms of individuals within their oun countries."

Committce I/I, 6 Documents of the United Nations Conference of International Organization, SAN Francisco, I945 29 r (I945). (Italics supplied.)

Four justices of the Supreme Court have, further, indicated a sense of obligation to take into account the policy embodied in the United Nations Charter in decisions about human rights. Justice Black, with whom Justice Douglas agreed, concurred in the California Alien Land Law case, Oyama v. California, 332 U. S. 633 ( 1948 ), declaring that one of the reasons why the law is bad is that "we have recently pledged ourselves to cooperate with the United Nations to "promote . . . universal respect for, and observance of, human rights and fundamental freedoms for all without distinction as to race, sex, language, or religion.' [citing the Charter, Articles 55c and 56] How can this nation be faithful to this international pledge if state laws which bar land ownership and occupancy by aliens on account of race are permitted to be enforced?" Id. at 649-650. And in the concurring opinion of Justice Murphy, who was joined by Justice Rutledge: "The Alien Land Law stands as a barrier to the fulfillment of that national pledge. Its inconsistency with the Charter, which has been duly ratified and adopted by the United States, is but one more reason why the statute must be condemned." Id. at 673 .

Compare the companion Canadian case, In re Drummond Wren, 4 D. L. R. 674 (1945).

For telling argument that the United Nations obligations are already "the law of the land," see Sayre, Shelley $\nu$. Kraemer and United Nations Law, 34 IowA L. Rev. I (1948), and United Nations Law, 25 Can. Bar. Rev. 809 (I947).

184 See Hutman Rights in The International Law Association, Report of the Forty-Second ConFerence, Prague, 1947 13, I4-15 (1948).

${ }^{155}$ Lauterpacht, stipra note 149 , at Ior, I02.

${ }^{100}$ Further evidence of the concern of the peoples of the world for human rights may be found in the Draft Declaration on Rights and Duties of States, just completed by the International Law Commission of the United Nations for submission to the General Assembly. Article 6 of this draft reads, 
by the bar leaders, Article 2(7) has proved little impediment to the competence of United Nations organs to take action in a number of situations which might from isolationist perspectives be regarded as involving "essentially" domestic questions. ${ }^{167}$ Thus, in the Spanish case in 1946 both the Security Council and the General Assembly took jurisdiction of questions about the nature of the Spanish government. In the view of the majority of the Council the Franco regime was regarded as likely to endanger international peace and security within the meaning of Article 34, a fact that called for action by the Council under Chapter VI (Pacific Settlement of Disputes). ${ }^{158}$ In reply to the objection that Article 2, paragraph 7, prohibited such action Dr. Evatt (an enthusiastic supporter of a broad scope for Article 2(7) at San Francisco) ${ }^{159}$ explained:

Then, I return to the object of the action in order to demonstrate that this matter is not essentially one of domestic concern. The object is to remove a danger to international peace and a cause of international friction.... The argument, therefore, that the United Nations and the Security Council or any other Members of the United Nations, cannot touch this matter, because it merely affects internal affairs in Spain is unsubstantial and should be rejected. ${ }^{160}$

And again:

If the facts indicate that that regime, by its nature, by its conduct, by its operation is likely to interfere with international peace and likely to be a menace to its neighbors, then the existence of that regime is no longer a matter of essentially domestic jurisdiction. ${ }^{161}$

The General Assembly on its part was even more emphatic. In support of a resolution adopted barring Spain from membership in the United Nations and recommending withdrawal of ambassadors, M. Alfaro of Panama stated:

But the dogma of non-intervention has nothing to do with the great system of col-

"Every state has the duty to treat all persons under its jurisdiction with respect for human rights and fundamental freedoms, without distinction as to race, sex, language, or religion."

Mr. Koretsky (Soviet Union) and Judge Hudson (United States) voted against the draft declaration. According to Sohn, The Development of International Law, 35 A.B.A.J. 688, 689 (r949): "Judge Hudson stated that he voted against the Draft Declaration because the provisions of its Article 6 went beyond the Charter of the United Nations and beyond international law at its present stage of development." It may be noted that Judge Hudson stood alone on this point and be re-emphasized that, whatever existing doctrine, there is no doctrine to preclude states from making new agreements.

${ }_{107}$ See FinchaM, op. cit. stipra note 115 , at ro3-1 40 for a convenient summary.

${ }^{158}$ Id. at I08-II3; Goodrich AND Hambro, op. cit. supja note II5, at 115.

${ }^{159}$ See 6 Documents of the United Nations Conference on International Organization, Sañ Francisco, r945 436 et seq. (1945). Dr. Evatt is responsible for the present limitation of the exception within Article 2, paragraph 7, namely, that authorization of intervention by the organization in cases arising under Chapter VII (Action with Respect to threats to the Peace, breaches of the Peace, and acts of Aggression)-see the final phrase of Art. $2(7)$-is limited to cases where enforcement measures under that Chapter are required.

${ }^{100}$ Journal of the Security Council No. 37 at 278, 279 (1947); quoted in Fintoham, op. cit. stupra note II5, at Iro-rir.

${ }_{101} I d$. at No. 39 at 767 , quoted in Fincham, op. cit. supra note 115 , at $113-114$. No resolution was adopted, however, despite approval by the Council, because the permanent members could not agree on a text. Goodrich and HAMBRo, op. cit. supra note 115, at 115 . 
lective action that we set up by the Charter at San Francisco. Arbitrary intervention infringes upon the principles of independence. Collective action is based on the doctrine of interdependence. Collective action is foreseen, authorized, and agreed upon in specific provisions of the Charter, and it is indispensable for the United Nations to exert, because without collective action we cannot have peace and security, we cannot promote human rights, we cannot have disarmament, we cannot make the trusteeship regime work, we cannot have international co-operation, we cannot accomplish any of the great, vital, basic principles, for which we have organized the world community of States. ...

To invoke Article 2, paragraph 7 of the Charter against this resolution is to miss the point entirely. We are not dealing here with any matter essentially within the domestic jurisdiction of Spain. We are making recommendations that concern only the individual sovereignty of the Members of the United Nations, because each nation is absolutely free to maintain or not to maintain ambassadors or ministers in any given country. I will conclude by stating that situations that are an actual or potential danger to the peace of the world, and constitute a continuous, notorious, grave and shocking violation of the most elementary human rights, are not matters essentially within the domestic jurisdiction of any particular State; they are essentially within international jurisdiction, essentially within the powers and duties of the United Nations. ${ }^{162}$

Likewise in the South African case the General Assembly assumed its competence and took jurisdiction, despite the objection that alleged discriminatory treatment of Indian immigrants by the Union of South Africa, in respect to suffrage and land tenure, was a matter essentially within the domestic jurisdiction of that country. ${ }^{163}$ When both the form of government of a state and internal discriminations are regarded as of "international concern" rather than of "domestic jurisdiction," it needs no emphasis that "domestic jurisdiction" is a concept of dwindling proportions. Further illustration could be offered by reference to the Greek and Indonesian cases. ${ }^{104}$ Whatever the actual facts of world-wide interdependence, it is clear that the representatives of the peoples assembled in the United Nations regard the human rights and security of all peoples as indivisible. It is difficult to believe that so many observers, from such different vantage points around the world and representing such diverse cultures, can all be be wrong.

The second major charge of the bar leaders that United States' participation in the United Nations program is unconstitutional as beyond the scope of the treaty or other federal power is equally without merit. Both Supreme Court opinion and the opinion of leading publicists make it clear, on the contrary, that our participation is well within the scope of the treaty and other federal power.

Undefined in the Constitution itself, the treaty power has always been regarded as sufficiently broad and expansible to cover all matters of genuine international

${ }^{202}$ Journal of the United Nations, No. 60, Supplement $A-A / P v / 59$, at 556 (I946); quoted in Fincham, op. cit. supra note $\mathrm{II}_{5}$, at $\mathrm{r}_{3} 8$.

${ }^{103}$ See Fincham, op. cit. supra note 115 , at $117-135$; Gross, Impact of the United Nations Upon Domestic Jurisdiction, 18 Dep't State Burl. 259, 263-264 (r948).

${ }^{154}$ See Fincham, op. cit. stipra note II5, at I04-107, II4-117; Gross, supra note I63, at 262. 
concern, under whatever conditions a changing world context may impose. No treaty has ever been held unconstitutional, ${ }^{165}$ and it is the general consensus that outside of certain wide limitations there is no subject about which a treaty may not be made. ${ }^{186}$ The prevailing interpretation of the several relevant clauses of the Constitution ${ }^{167}$ was most clearly expounded by the Supreme Court in a famous passage in Geofroy v. Riggs in $1890::^{188}$

The treaty power, as expressed in the Constitution, is in terms unlimited except by those restraints which are found in that instrument against the action of the government or of its departments, and those arising from the nature of the government itself and of that of the States. It would not be contended that it extends so far as to authorize what the Constitution forbids, or a change in the character of the government or in that of one of the States, or a cession of any portion of the territory of the latter without its consent. ... But with these exceptions, it is not perceived that there is any limit to the questions which can be adjusted touching any matter which is properly the subject of negotiations with a foreign country. ${ }^{109}$

It is immediately apparent that the limitations as to agreements which seek basically to change the Constitution or "authorize what the Constitution forbids" are not relevant to the present question. Only the grossest distortion of perspectives could envisage the human rights program as interfering, for example, with a republican form of government ${ }^{170}$ or seeking to establish a religion. The only relevant limita-

${ }^{105}$ See Devlin, The Treaty Power Under the Constitution of the United States 128 \$3 (1908).

${ }^{200}$ See Feidler and Dwan, The Extent of the Treaty-Making Power, 28 Geo. L. J. 184 (1939); Burr, Treaty-Making Power, 51 Proc. Am. Phic. Soc'y 27I (1912); Butler, Limitations of the Treaty-Making Power of the United States in Matters Coming Within the Jurisdiction of the States, 23 Proc. Ar. Soc'y INT'L L. 176 (1929); Hughes, id. at 194; Boyd, The Expanding Trealy-Power, 6 N. C. L. REv. 428 (xg28); Lenoir, Treaties and the Supreme Court, I U. of CH. L. Rev. 602 (1934); Kuhn, The Treaty-Making Power and the Reserved Sovereignty of the States, 7 Cor. L. REv. 172 (1907); Magnusson, Our Membership in the United Nations and the Federal Treaty-Power Under the Constitution, 34 VA. L. REv. 137 (1948); Hudson, The Treaty-Making Power of the United States in Connection with the Manufacture of Arms and Ammunition, 28 AM. J. Int'L L. 736 (1934); EDward S. Corwin, The Constiturion and Worid Organization (1944); Nattonal Supreascy Versus State Power (igi3); Total War and the Constitutton c. 4 (1947); 1 W. W. Willoughby, The Constitutional Law of the United States \$215 (I910); 2 Joseph Story, Commentaries on the Constitution of the United States \$1508 (3rd ed. 1858); Abraham Weinfeld, Labor Treatres and Labor Compacts (1937); 2 Charles H. Butrer, Treaty-Making Power of the United States (1902); 2 Chas. C. Hyde, International Law, Chiefty As INTERPReted AND APplied by the UNITEd States 139i (2d rev. ed. 1945).

Legislation enacted pursuant to the treaty-power and co-extensive with it is covcred by the same rule. Where a treaty is validly made "there can be no question whether the subsequent legislation to carry out the treaty is constitutional." Feidler and Dwan, stspris note 166 , at 197; see Anderson, Extent and Limitations of the Treaty Power, I AM. J. INT'L L. 636, 657 (1907); Missouri v. Holland, 252 U. S. 416,432 (1920); Neely v. Henkel, I80 U. S. I09 (Igor).

${ }_{107}$ The important grants of power are of course Art. II, Sec. 2, Par. 2, which reads:

"He [the President] shall have the power, by and with the advice and consent of the Senate, to make treaties, provided two-thirds of the Senators present concur . . " and Art. VI, Par. 2, which reads:

"This Constitution, and the laws of the United States which shall be made in pursuance thereof, and all treaties made, or which shall be made, under the authority of the United States, shall be the Supreme law of the land; and the judges in every State shall be bound thereby, anything in the Constitution or laws of any State to the contrary notwithstanding."

${ }^{108} 133$ U. S. 258 (1890) (Treaty of 1853 with France permitting aliens to inherit property, held superior to contrary law of Maryland, which was applicable in the District of Columbia where case arose).

${ }^{100}$ Id. at $26 \%$.

${ }^{170}$ Butler, Limitations of the Treaty-Making Power of the United States in Matters Coming Within the Jurisdiction of the States, 23 Proc. Am. Soc. INr'L L. 176, 178 (1929). 
tion (beyond the safeguards of the Fifth Amendment, to be discussed below) is that which limits the subject matter of a treaty to questions "that properly pertain to our foreign relations." ${ }^{171}$ Chief Justice Hughes expressed, this point succinctly:

It seems to me that, whatever doubt there may originally have been or may yet linger in some minds in regard to the scope of the treaty-making power, so far as it relates to the external concerns of the nation there is no question for discussion. I think it perfectly idle to consider that the Supreme Court would ever hold that any treaty made in a constitutional manner in relation to external concerns of the nation is beyond the power of the sovereignty of the United States or invalid under the Constitution of the United States where no express prohibition of the Constitution has been violated. ${ }^{172}$

The still leading case on the scope of the treaty power is Missouri $v$. Holland, ${ }^{173}$ holding that the treaty power may be extended even beyond the limits of the powers expressly delegated to the Congress, when those powers are too narrowly construed to permit effective action on matters of national interest and international concern. The decision in this case sustained an act of Congress, adopted under the "necessary and proper" clause, to implement a treaty made with Great Britain for the protection of migratory birds traveling between the United States and Canada. Two lower courts had held unconstitutional an earlier act of Congress, not in aid of a treaty but designed to secure the same end. ${ }^{174}$ Speaking for the Court, Justice Holmes said:

Whether the two cases cited were decided rightly or not they cannot be accepted as a test of the treaty power. Acts of Congress are the supreme law of the land only when made in pursuance of the Constitution, while treaties are declared to be so when made under the authority of the United States. It is open to question whether the authority of the United States means more than the formal acts prescribed to make the convention. We do not mean to imply that there are no qualifications to the treatymaking power; but they must be ascertained in a different way. It is obvious that there may be matters of the sharpest exigency for the national well being that an act of Congress could not deal with but that a treaty followed by such an act could, and it is not lightly to be assumed that, in matters requiring national action, "a power which must belong to and somewhere reside in every civilized government" is not to be found.... [W] [Wen we are dealing with words that also are a constituent act, like the Constitution of the United States, we must realize that they have called into life a being the development of which could not have been foreseen completely by the most gifted of its begetters. It was enough for them to realize or to hope that they had created an

\footnotetext{
${ }^{171}$ Santovincenzo v. Egan, 284 U. S. 30,40 (r93I). Cf. Asakura v. Seattle, 265 U. S. $332,34 \mathrm{I}$ (1923); Holden v. Joy, I7 Wall. 211,243 (U. S. I872).

${ }^{173}$ Hughes, supra note I66, at 194. (Italics supplied.) For other authorities adhering to the same view see: Edward S. Corwin, National Supremacy Versus State Power (1913); Burr, supra note 166, at 285 . Judge Hudson states:

". . . it is essential that within very wide limits the Government of the United States should have power to do by treaty what is thought to be for the interests of the United States, and no construction of the Constitution which would deprive it of such power is to be tolerated."

Hudson, stpra, note $I 66$, at 738 .

${ }^{173} 252$ U. S. 416 (I920).

174 See United States v. McCullagh, 221 Fed. 288 (D. Kan. 1915); United States v. Shauver, 214 Fed. I54 (E. D. Ark. I9 4 ).
} 
organism; it has taken a century and has cost their successors much sweat and blood to prove that they created a nation. The case before us must be considered in the light of our whole experience and not merely in that of what was said a hundred years ago. The treaty in question does not contravene any prohibitory words to be found in the Constitution. The only question is whether it is forbidden by some invisible radiation from the general terms of the Tenth Amendment. We must consider what this country has become in deciding what that Amendment has reserved. . . . No doubt the great body of private relations usually fall within the control of the State, but a treaty may override its power. . . . Here a national interest of very nearly the first magnitude is involved. It can be protected only by national action in concert with that of another power. ${ }^{175}$

What is of "external" or "international" concern, it may be added, need not be exclusively so. In many instances, if not in most, there is a concurrence of interest which has both domestic and foreign application. Local matters can, as in the Holland case they did, become as Hughes suggests "so related to international matters that an international regulation could not appropriately succeed without embracing local affairs as well."176

It may reasonably be assumed that what are matters of international concern for determining the scope of the treaty power is in the last analysis a question, not of derivation from authoritative doctrine, but of fact and of contemporary fact. The concern of the peoples of the world for human rights and the international character of such rights for the purposes of international law have already been sufficiently demonstrated. Nothing in the context of the creation of our Constitution or in the subsequent history of our constitutional development offers any barrier to the conclusion that human rights are equally of international concern for exercise of the treaty power. The constitutional framers plainly foresaw the possibilities of unanticipated development in the scope of the treaty power, as Madison's reluctance to specify its content shows:

The object of treaties is the regulation of intercourse with foreign nations and is external. I do not think it possible to enumerate all the cases in which such external regulations would be necessary. Would it be right to define all the cases in which Congress could exercise this authority? The definition might and probably would be defective. They might be restrained by such a definition from exercising the authority where it could be essential to the interest and safety of the community. It is most safe, therefore, to leave it to be exercised as contingencies may arise. ${ }^{177}$

It is both certain that the framers could not have foreseen as the subject of treaties such items as patents, copyrights, health, drugs, labor relations, commercial aviation, armaments, and a host of matters which have become questions of international concern since $1787,{ }^{178}$ and equally clear from Madison's remarks that they did not see "external" matters as a fixed and unalterable category. And if this category was not

${ }^{175} 252$ U. S. $416,433-434,435$ (1920).

${ }^{178}$ Hughes, supra note 166 , at $\mathrm{x} 95$; see also Feidler and Dwan, supra note $\mathrm{I} 66$, at 195.

${ }^{177} 3$ Elliotr's Debates $51_{4}$ (2d. ed. 1836-I866) (Italics supplied); see Devlin, op. cit. silpra note 165 , at 128 .

${ }^{178}$ See WeInfend, op. cit supra note 166, at 25; also Comment, Treaties and the Constitution: Alien Property Rights, 37 Cor. L. REv. 136r (1937). 
intended to be fixed, and has not proved to be so in practice, "then it is obvious" as one authority points out "that the limits of the [treaty] power are coeval and coterminous with the increasing and expanding nature of the relations between nations." 179 In the face of world problems and interdependences involving every aspect of human activity to a degree unimagined even a few years ago, it seems unreal and foolish-even dangerous-to rest any question of fact or policy on a view which holds that the migration of birds can be a matter of international concern, but that the liberty and welfare of human beings cannot.

It is now generally agreed, as indicated by Justice Holmes in Missouri v. Holland, ${ }^{180}$ that the scope of the treaty power is in no way limited by the powers otherwise reserved by the Constitution to the states or by any "invisible radiation from the general terms of the Tenth Amendment."181 On no point have the Supreme Court and leading authorities been more emphatic. "The powers of the states ... set no limit to the treaty-making power."182 The celebrated case of Ware $v$. Hylton, $^{183}$ which held the Treaty of Peace with Great Britain in 1783 paramount to a Virginia statute discharging debts due British subjects, speaks with unusual authority since one of the justices had been a member of the Federal Convention and another of a State Convention adopting the Federal Constitution. ${ }^{184}$ Speaking for the Court Justice Chase laid down the rule which with only inconsequential deviation ${ }^{185}$ has continued to the present day:

It seems to me that treaties made by congress according to the confederation, were superior to the laws of the States; because the confederation made them obligatory on all the States. ... .

[But] if doubts could exist before the establishment of the present national government, they must be entirely removed by the sixth article of the constitution which provides "that all treaties made or which shall be made under the authority of the United States, shall be the supreme law of the land. . . " It is the declared will of the people of the United States that every treaty made by the authority of the United States shall be superior to the constitution and laws of any individual state; and their will alone is to decide. ${ }^{180}$

The subjects covered in application of this principle have repeatedly extended to matters ordinarily left to regulation by the states. In addition to abrogation of debts in the case just mentioned these include: title to land, ${ }^{187}$ escheat and inheri-

${ }^{170}$ Boyd, supra note 166 at $44 \mathrm{I}$. $\quad{ }^{180}$ Supra note $173 . \quad{ }^{181}$ Id. at 434.

${ }^{282}$ Edward S. Corwin, The Constitution and What It Means Today iot (roth ed. i948).

${ }^{183} 3$ Dall. 199 (U. S. 1796). Cf. Clarke v. Harwood, 3 Dall. 343 (U. S. 1797).

184 These were Justice Wilson and Justice Iredell. See Butler, supra note I70, at 179.

${ }^{185}$ Arising from concern for slave-holding interests, the doctrine that the scope of the treaty-power could not extend to matters reserved to the states, was put forward as dicta by Chief Justice Taney in Provost v. Greneaux, I9 How. I (U. S. 1856) (treaty with France held intended not to supersede Louisiana state succession tax law). See Edward S. Corwin, The Construtuon and World OrganizaTION 13-14 (1944); 2 WILloughBY, op. cit. supra note 166, secs. 213-215. For authority overruling this decision see cases cited infra note 188. Cf. 2 WilloughBY, secs. 214-2r5.

${ }^{180} 3$ Dall. 199, at 236, 237 (U. S. 1796).

${ }^{287}$ Fairfax's Devisee v. Hunter's Lessee, 7 Cranch 603 (U. S. 1813) (involving title under Virginia law as opposed to Treaty of 1794 with Great Britain). Cf. Hughes v. Edwards, 9 Wheat. 489,496 (U. S. 
tance, ${ }^{188}$ statute of limitations, ${ }^{189}$ local taxation, ${ }^{100}$ administration of alien estates, ${ }^{101}$ prohibition against employment of foreign labor, ${ }^{102}$ and the limitation of pawnbrokerage to citizens. ${ }^{193}$ Nor is the predilection for national supremacy confined to federal courts. State courts also have presented and rejected the states-rights argument. ${ }^{194}$ The contention that most of these subjects have involved aliens and thus form a particular category of state-supervised activity has little merit in the face of Missouri $v$. Holland, ${ }^{195}$ which made applicable to American citizens regulations respecting the preservation of birds. And there is no need to suppose the end of this development has been reached. Many years ago Professor Borchard observed:

It is within the power of the federal government by treaty to remove from state control any matter which may become the subject of negotiation with a foreign government. With the continued drawing together of the world by increased facilities for travel and communication, the subjects of common interest which require international regulation will continue to grow in extent and variety. Uniformity of legislation by withdrawal from state legislative control of such subjects as marriage and divorce, labor legislation, the ownership and inheritance of property, and all matters affecting alicns would be possible by the exertion of the necessary federal treaty power. ${ }^{100}$

Only the narrowest perspective could except the human rights program from the scope otherwise so broadly conceived.

Coming explicitly to the Tenth Amendment, it is clear that this famous constitutional truism imposes no limit on the treaty power. Nowhere in the constitutional debates, either federal or state, is there any indication that such limitation was contemplated. As Burr points out:

The very language of the amendment would seem to establish this fact. What are the powers reserved to the States thereby? "The powers" first, says the amendment, "not delegated to the United States," and second, adds the amendment, not "prohibited by it"

I824) (Kentucky statute barring alien land holding); Society for the Propagation of the Gospel v. New Haven, 8 Wheat. 464 (U. S. 1823). See for these and the following cases, notes infra 188-193, Feidler and Dwan, stipra note i66; Abrafiam Weinfeld, Labor Treaties and Labor Compalts i 4 et seq. (1937); Kuhn, supra note 166.

${ }_{188}$ Chirac v. Chirac, 2 Wheat. 259 (U. S. 1817) (Maryland escheat law abrogated by treaty with France); Hauenstein v. Lynham, roo U. S. 483 (1879) (common law and statutory law of Virginia overruled by Swiss Treaty of I850); Santovincenzo v. Egan, 284 U. S. 30 (I93I) (treaty with Persia and New York escheat law).

${ }^{280}$ Hopkirk v. Bell, 3 Cranch 454 (U. S. I 806) (Virginia statute of limitations).

${ }^{100}$ Neilsen v. Johnson, 279 U. S. 47 (I929) (I826 Treaty with Denmark superior to Iowa tax law).

101 These are the consular cases. See e.g., In re Faltosini, 67 N. Y. Supp. IxI9 (I900); In re Lobrasciano, 77 N. Y. Supp. I040 (I902); Wyman v. McEvoy, 191 Mass. 276, 77 N. E. 379 (1906). See Kuhn, stcpra note 166 , at 180 . For a more recent discussion of the cases sec Comment, Treaties and the Constitution: Alien Property Rights, 37 CoL. L. Rev. 136r (r937). Cf. Rocea v. Thompson, 223 U. S. $317,330-33$ I (r9r2), holding that although it was within the power of the national government to confer the exclusive right of administration of alien intestate estates on consuls, the words of a particular treaty might not require the contravention of state law. See Comment, stipra, at 1367-1368.

${ }^{102}$ Baker v. City of Portland, 2 Fed. Cas. 472 , No. 777 (C. C. D. Ore. 1879).

${ }^{103}$ Asakura v. Seattle, 265 U. S. 332 (I924) (involving treaty of I9Ir with Japan).

106 Especially Opel v. Shoup, 100 Iowa 407, 420 (r896); see Kuhn, stipra note 166, at 180, n. I. ${ }^{105}$ Supra note 173 .

${ }^{100}$ Comment, Treaty-Making Power as Support for Federal Legislation, 29 YALE L. J. 445,449 (I920). 
[the Constitution] to the States. Now, by the Constitution the power to make treaties is specifically granted to the Federal government in the Second Section of the Second Article, and specifically prohibited to the States by the Tenth Section of the First Article. ... The reserved rights of the States are necessarily and by virtue of the very words of the Tenth Amendment, those rights which remain after the grant, first, of the treaty-making power, and second, of the power of Congress to legislate upon certain subjects. The Tenth Amendment, therefore, leaves the treaty-making power of the United States unaltered and precisely as granted by the Constitution. ${ }^{\mathbf{1 9 7}}$

The cases, already referred to, holding treaties superior to state law confirm this position. If, as has been held, the Tenth Amendment is merely "declaratory" and of no effect as to a bar to broad congressional powers under the commerce clause, ${ }^{198}$ it has even less cause to be revived in order to cut down the treaty power. The conclusion is thus inevitable: the Amendment is wholly immaterial, both as to the provisions of treaties themselves and to the legislation supplementing them. ${ }^{199}$

The wisdom of the conclusion that state power does not restrict treaty power is demonstrated by a glance at the alternative. "Were it true," it is suggested, "that the United States could not enter into treaties affecting matters understood to be generally reserved to the States ... the result would be an intolerable restriction upon the power of a sovereign nation."200 The United States would not in fact be sovereign in the sense of having real power to protect itself in world affairs, a point which Justice Holmes emphasized in Missouri v. Holland in urging that "it is not lightly to be assumed that, in matters requiring national action, 'a power which must belong to and somewhere reside in every civilized government' is not to be found." 201

It is, if possible, even more firmly established that the scope of the treaty power is not limited by the powers otherwise delegated by the Constitution to the whole Congress. Though the treaty-power and the delegated and inherent powers of Congress frequently refer to the same events in our international affairs they are concurrent, not conflicting. ${ }^{202}$ It is suggested by Professor Corwin that the power

107 Burr, supra note 166 , at $362-363$.

${ }^{108}$ Speaking for the Court in United States v. Darby, 3 I2 U. S. 100, I24 (1940), which overruled Hammer v. Dagenhart, 247 U. S. 25 I (I9x8), Justice Stone stated:

"The amendment states but a truism that all is retained which has not been surrendered. There is nothing in the history of its adoption to suggest that it was more than declaratory of the relationship between the national and state governments as it has been established by the constitution before the amendment or that its purpose was other than to allay fears that the new national government might seek to exercise powers not granted, and that the states might not be able to exercise fully their reserved powers. . . . From the beginning and for many years the amendment has been construed as not depriving the national government of authority to resort to all means for the exercise of a granted power which are appropriate and plainly adopted to the permitted end."

See Feller, The Tenth Amendment Retires, 27 A. B. A. J. 223 (194r); Comment, 37 CoL. L. Rev. 1361,1362 (1937).

${ }^{100}$ See note 166 supra. $\quad{ }^{200}$ Note, 33 Harv. L. Rev. 281, 287 (I9I9).

${ }^{201} 252$ U. S. $4 \mathrm{r} 6,433$ (1920). For further comment on this point sce EDward S. Corwin, The Constitution and World Organization 14-15 (1944); Hughes, supra note 166, at I94; Butler, supra note 170 , at 178 .

${ }^{202}$ See Burr, supra note I66, at 306; Kuhn, supra note 166 , at $\mathrm{x} 83 ; 5$ JoHN B. MOORE, INTERNATIONAI Law Digest I64 (1906). The cases are collected in Abraham Weinfeld, Labor Treattes and Labor Compacts 25 et seq. (1937). 
to appropriate money and possibly to incorporate territory are exceptions. ${ }^{203}$ But with that question we need not concern ourselves here, neither problem having relevance to the human rights program. It is sufficient to note that treaties have dealt again and again with subjects otherwise delegated to Congress. Witness, for example, the array of agreements, which might otherwise be regulated under the commerce power, affecting customs duties and regulating commerce. ${ }^{204}$ Treaties have also extended to copyrights, naval armament, and taxation, each of which equally comports with a specifically granted congressional power. ${ }^{205}$ That there is no conflict is evidenced in the unquestioned rule of law that treaties may supersede prior congressional acts. On this point it was stated in Foster $v$. Neilson, ${ }^{206}$ a case involving the validity of the Spanish grants in West Florida and the effect to be given to the Treaty of r8rg with Spain: "Our constitution declares a treaty to be the law of the land. It is, consequently, to be regarded in Courts of Justice as equivalent to an act of the legislature, whenever it operates of itself without the aid of any legislative provision."207 This is not to say that the converse is not also true, that an act of Congress of later date may not override, from the point of view of domestic law, the provisions of a treaty. ${ }^{208}$ But this fact is irrelevant to the question of limitation of the treaty power; it is only concerned with the termination of individual rights created by treaty and, moreover, as to that termination extends only to the internal domestic effectiveness, since no congressional act can abrogate a treaty in terms of international obligation. ${ }^{209}$ It has no bearing on the scope of subjects which a treaty may embrace, nor on the international effectiveness of such a treaty. Speaking of the Chinese Exclusion case, ${ }^{\mathbf{2 1 0}}$ which concerned just such an abrogation by act of Congress of the Treaty of 188I with China, Burr remarks:

Yet nowhere creeps in a suggestion that the provisions of the treaties with China dealing with and regulating commerce and immigration, are ineffective as laws; indeed, the cases are suffused with the light of the contrary assumption and constitute direct and

${ }^{203}$ Enward S. Corwin, National Supremacy Versus State Power 9-13 (I913).

$204 \mathrm{Cf}$. Commercial aviation, trade-marks, agriculture, trade in dangerous drugs, traffic in women, to list a few. See WeInferd, op. cit. stupra note 166, at 5; CoRwin, op. cit. supra note 203, at Ix, and cases therein cited: McDougal and Lans, Treaties and Congressional-Exectutive or Presidential Agreements: Interchangeable Instruments of National Policy, 54 YALE L. J. 180, 273-278 (1945). On this point Burr remarks:

"Inasmuch as the Supreme Court has spoken so often, so uniformly, so positively, upon the question discussed in the preceding cases, it would seem almost a work of super-erogation to inquire how many treaties have been made regulating commerce, and put into effect without any act of Congress." Burr, supra note 166 , at 322 .

${ }^{205}$ See WeINFELd, op. cit. supra note 166 , at 5,30 .

${ }^{200} 2$ Pet. 253 (U. S. 1829 ).

${ }^{207}$ Id. at $3 \mathrm{I} 4$.

${ }^{208}$ Two Hundred and Seven Half Pound Papers of Smoking Tobacco, ete. v. United States, II Wall. 616 (U. S. 1870); Whitney v. Robertson, 124 U. S. 190 (1887); Edye v. Robertson, Ir2 U. S. 423 (1884).

${ }^{200}$ See Riesenfeld, The Power of Congress and the President in International Relations: Three Recent Supreme Coutr Decisions, 25 Calif. L. REv. 643, 656-661 (1937). Compare Jones, Constitutional Limitations on the Treaty-Making Power, 35 AM. J. INT'1 I. 462 (194I), which deals with the international aspects of the problem.

${ }^{210}$ Chae Clan Ping v. United States, 130 U. S. 581 (1888). 
positive decisions recognizing and establishing the efficacy of treaty provisions propriore vigore. 211

From the preponderance of cases in this vein and of like authoritative opinions it is clear that congressional powers impose no constitutional bar to the protection of human rights through the treaty power.

A very good case can indeed be made for the converse proposition that the treaty power imposes no limits on the powers of the whole Congress and that there exists through a combination of the powers of the Congress and the President a plenary federal power over foreign affairs which offers a procedure, completely interchangeable with and alternative to the treaty, for the making and implementation of international agreements. ${ }^{212}$ It is not disputed today that the President has exclusive control over the actual conduct of all negotiations with other nations and that he is the appropriate authority to make final utterance of an agreement as the international obligation of the United States. ${ }^{213}$ It is likewise clear that the whole Congress has wide powers, granted by the express terms of the Constitution and exercised in hundreds of instances since the beginning of our history, to frame policies to guide the President in his conduct of negotiations and to validate agreements negotiated by him as the law of the land. ${ }^{214}$

The Congress has broad powers "to ... provide for the common defense and general welfare of the United States,"215 "to regulate commerce with foreign nations, and among the several States,"210 to define and punish ... offenses against the law of nations,"217 "to declare war,"218 "to make all laws which shall be necessary and proper for carrying into execution the foregoing powers, and all other powers vested by this constitution in the Government of the United States, or in any depart-

311 Burr, stupra note $x 66$, at 318 .

${ }^{212}$ For 250 pages of documentation of the general point, see McDougal and Lans, Treaties and Congressional-Executive or Presidential Agreements: Interchangeable Instruments of National Policy, 54 Yale L. J. I8I, 534 (1945). See also Edward S. Corwin, The Constitution and Wordo Organization 8 (1944); Wallace M. McClure, International Executtve Agreements; Democrattc ProCEDURE UNder the ConstTtution of the United States (1941); Wright, The United States and International Agreements, 38 Ax. J. INT'L L. 34I (I944); Dickey, Our Treaty Procedure Versus Our Foreign Policies, 25 Foreign Afratrs I (1947).

${ }^{213} \mathrm{McD}$ ougal and Lans, supra note 212, at 244 et seq.; Wright, supra note 212, at 355.

${ }^{214} \mathrm{McD}$ ougal and Lans, stipra note 212, at 238 et seq.; Hackworth, Legal Aspects of the Trade Agreements of 1934,21 A. B. A. J. 570 (1935).

${ }^{210}$ U. S. Const. Art. I, $\$ 8$, par. I.

${ }^{220}$ Id. par. 3. It may be noted that the Supreme Court did not hold in Missouri $\nu$. Holland, supra note 173, that the commerce power did not extend to regulating the flight of birds. It assumed the point arguendo. Justice Holmes' dictum that the treaty power might extend beyond the scope of the powers expressly delegated to the Congress was uttered before the Court had officially declared the Tenth Amendment a truism for all purposes, before the Court had reverted to the early broad interpretations of the commerce power, and before the doctrine of "inherent powers" had received its present broad application to agreements other than treaties. It is not to be expected that future courts will regard a dictum uttered in such a context as imposing any serious limit on the powers of the Congress. For discussion, see McDougal and Lans, supra note $2 \times 2$ at 285 .

${ }^{217}$ Id. par. Io.

${ }^{218}$ Id. par. Ir. 
ment or officer thereof,"219 and, hence, to implement the Bill-of-Rights ${ }^{220}$ amendments to the Constitution; and these powers are coming to be more and more broadly construed as the exigencies of the nation require. Thus, the war power is held not restricted to "the winning of victories in the field and the repulse of enemy forces," but to extend to "every matter so related to war as substantially to affect its conduct and progress."221 Embracing the daily intricacies of the national economy, this power has been invoked to sustain as late as in 1948 the Housing and Rent Act of 1947 on the ground that war does not end with the cessation of hostilities. Similarly, the Supreme Court, in Justice Murphy's words, now insists "that the federal commerce power is as broad as the needs of the nation" and that it cannot "deny that Congress can effectively deal with problems concerning the welfare of the national economy."222 The foreign commerce clause shares this broad construction and has been held to sustain tariff duties which could not be upheld under the tax power. Speaking for a unanimous court in this case, University of Illinois $v$. United States, ${ }^{23}$ Justice Hughes commented: "In international relations and with respect to foreign intercourse and trade, the people of the United States act through a single government with unified and adequate national power."224 The power of Congress to control aliens, though not a specifically delegated power, charts the same course. In Fong Yue Ting v. United States, ${ }^{225}$ Justice Gray upheld deportation of aliens at the option of Congress saying:

The United States are a sovereign and independent nation, and are vested by the Constitution with the entire control of international relations, and with all the powers of government necessary to maintain that control and make it effective. The only government of this country, which other nations recognize or treat with, is the Government of the Union ...226

And more recently a Pennsylvania statute which sought to regulate aliens was held unconstitutional, as a violation of the principle of supremacy. ${ }^{227}$ "The supremacy of the national power," said Justice Black for the Court, "in the general field of foreign affairs, including power over immigration, naturalization and deportation, is made clear by the Constitution, was pointed out by the authors of The Federalist in $\mathbf{1 7 8 7}$, and has since been given continuous recognition by this Court."228

Supplementing these powers of the Congress, the powers of the President as "the Executive," 220 as "the Commander-in-Chief of the the Army and Navy,"

${ }^{210} \mathrm{Id}$. par. $\mathrm{x} 8$.

${ }^{220}$ For the broad federal powers over civil rights and liberties which can be used to authorize international agreements see infra, Section VI. The President's Commitree on CiviL Rights, To Securze THESE RIGHTS I07 (1947) offers a survey of the relevant constitutional powers.

${ }^{221}$ Chief Justice Stone for the Court in Firabayashi v. United States, 320 U. S. 81, 93 (1942).

222 American Power and Light Co. v. S. E. C., 329 U. S. 90,103 (1946).

${ }^{223} 289$ U. S. 48 (1933).

${ }^{225} 149$ U. S. 698 (1893).

227 Hines v. Davidowitz, 312 U. S. 52 (1940).

${ }^{220}$ U. S. CoNST. Art. II, §I, par. I.

${ }_{224}$ Id. at 59 .

$2201 d$. at $7 \mathrm{xr}$.

${ }_{228}$ Id. at 62 .

${ }^{230} I d$. §II, par. $\mathrm{x}$. 
and as agent for Congress, make up a full complement of powers adequate to deal with all phases of international life. Independent of Congress, the President may negotiate agreements with foreign nations within the scope of his own delegated powers, ${ }^{231}$ while as agent for Congress, under its powers as recited above, it has been customary for the President since $x 792$ to negotiate international agreements on a great range of important topics of ever increasing variety. ${ }^{232}$ How far the powers of the President alone extend, it is not necessary to speculate; it is sufficient for present purposes that the powers of Congress when conjoined with those of the President are plenary.

To augment the express powers of the Congress and the President, to close any conceivable gaps, and hence to insure the plenary character of these powers in any eventuality, there is available a well-established doctrine, the doctrine of "inherent powers" in international affairs, which "has had a long and honorable history of effective work in the national interest,"233 and which in one form or another is subscribed to by most commentators on the Constitution. ${ }^{234}$ The most famous recent exposition of this doctrine is that of Justice Sutherland, speaking for the Court, in United States v. Curtiss-Wright Corporation. ${ }^{235}$ Upholding the power of the President to impose by proclamation, pursuant to a Joint Resolution of Congress, an embargo on the shipment of arms, Justice Sutherland clarified the difference between federal powers in the domestic and in the international field, saying: $:^{\mathbf{2 3 5}}$

The two classes of powers are different, both in respect of their origin and their nature. The broad statement that the Federal government can exercise no powers except those specifically enumerated in the Constitution, and such implied powers as are necessary and proper to carry into effect the enumerated powers, is categorically true only in respect of our internal affairs. . . .

It results that the investment of the Federal government with the powers of external sovereignty did not depend upon the affirmative grants of the Constitution. The powers

${ }^{231}$ Sec McDougal and Lans, supra note 212, at 246-252. Cf. United States v. Belmont, 301 U. S. 324 (1937).

${ }_{232}$ See B. Altman \& Co. v. United States, 224 U. S. 583 (1912); Field v. Clark, 143 U. S. 649 (I892); Hampton and Co. v. United States, 276 U. S. 394 (1928). McDougal and Lans, supra note 212, at 252254,273 et seq. In addition to commercial agreements some of the subjects covered are acquisition of territory, settlement of international claims, adherence to international organizations (see I. L. O., Universal Postal Unions, International Penal Prison Commission, UNRRiA, Bretton Woods, etc.), and international financial and war debt agreements. Id. at 261-263, 278-282.

${ }^{233} \mathrm{McD}$ ougal and Lans, supra note 212 , at 255.

If it be suggested that this completely comprehensive power of the Federal Government over foreign affairs can exhaust itself through the treaty power, Professor Corwin in THE Constrturtion and WoRLD Organization ig (1944) answers:

"As a matter of history the notion of the indefinite scope of the treaty-making power is itself reflective of the concept of the National Government's plenary powers in the field of foreign relation and was not always conceded in earlier days."

234 For the semantic equivalence of doctrines of "implied powers" and "constructive powers," with citation to various authorities, see McDougal and Lans, stupra note 212, at 256 et seq. See also Edward S. Corwin, The Constitution and World Organization 17-20 (1944), The President, Office and Powers 209-2I I (3rd rev. ed. I948); Culp, Executive Power in Emergencies, 3I Mrch. L. REv. II62 (I93I).
${ }^{236} 299$ U. S. 304 (I936).
${ }^{2352} I d$. at 318 . 
to declare and wage war, to conclude peace, to make treaties, to maintain diplomatic relations with other sovereignties, if they had never been mentioned in the Constitution, would have vested in the Federal government as necessary concomitants of nationality. Neither the Constitution nor the laws passed in pursuance of it have any force in foreign territory unless in respect of our own citizens ...; and operations of the national in such territory must be governed by treaties, international understandings and compacts, and the principles of international law. As a member of the family of nations, the right and power of the United States in that field are equal to the right and power of the other members of the international family. Otherwise, the United States is not completely sovereign. The power to acquire territory by discovery and occupation, (Jones v. United States, 137 U. S. 202, 212), the power to expel undesirable aliens (Fong Yue T'ing $v$. United States, 149 U. S. 698,705 et seq.), the power to make such international agreements as do not constitute treaties in the constitutional sense (Altman \& Co. v. United States, 224 U. S. 583, 600, 60x; Crandall, Treaties, Their Making and Enforcement, 2d ed., P. I02 and note I), none of which is expressly affirmed by the Constitution, nevertheless exist as inherently inseparable from the conception of nationality.

From this decision and others it is clear that neither the doctrine of enumerated powers nor the separation of powers ${ }^{236}$ doctrine has the slightest force in impeding the comprehensive and effective cooperation of the President and Congress in the field of international relations. ${ }^{237}$

In the light of these facts, it may be concluded that the United States has a choice of procedural alternatives-treaty or congressional-executive agreement, and each fully competent-for implementing its participation in the human rights program. As emphasized by Professor Garner, Reporter for the Harvard Research Draft of the Law of Treaties, any particular choice between these alternatives is "a matter of practical convenience or political expediency rather than of constitutional law." "If the procedure of treaty regulation proves ineffective in a particular case because of the constitutional impediment relative to ratification," writes Professor Garner, "there is no reason of constitutional or international law why recourse to the easier alternative of legislative action cannot be had, if the President and a

${ }^{238}$ Edward S. Corwin, The Constitution and Wordd Organization 23 (1944); Ricsenfeld, supra note 209 , at $674-675$.

${ }_{237} \mathrm{It}$ should be noted that congressional-executive agreements are effective as the "law of the land" and have the same overriding effects as treaties in respect to state law. This is true even of Presidential agreements. For distinguished authority see United States v. Belmont, 301 U. S. 324 (1937); United States v. Pink, 315 U. S. 203 (1942). Justice Sutherland for the Court declared in the carlier case:

"Plainly, the external powers of the United States are to be exercised without regard to state laws or policies. The supremacy of a treaty in this respect has been recognized from the beginning. ... In respect of all international negotiations and compacts, and in respect of our foreign relations generally, state lines disappear. As to such purposes the Statc of New York does not exist. Within the field of its powers, whatever the United States rightfully undertakes, it necessarily has warrant to consummate. And when judicial authority is invoked in aid of such consummation, state constitutions, state laws, and state policics are irrelevant to the inquiry and decision. It is inconceivable that any of them can be interposed as an obstacle to the effective operation of a federal constitutional power."

Id. at 33I-32. This language is quoted with approval by Justice Douglas in the Pink case, stipra, at 223. For succinct summary of this point see United States $v$. Pink-A Re-appraisal, 48 Col. L. Rev. 890, 896-7 (1948). 
majority of the two Houses of Congress so desire, as has been done with success on various occasions in the past."238

To establish that federal power over foreign affairs, whether exercised by treaty or congressional-executive agreement, is ample to implement an effective covenant on human rights, it is not necessary to establish, as the bar leaders demand, that this power is limitless. So long as the Supreme Court sits, honors the Fifth Amendment, and is able to make its decrees effective, the tyranny they fear is illusory. The safeguards of the Fifth Amendment and the other Bill-of-Rights provisions, stand unquestionably in the way of abuse of power over foreign affairs. While it is true that there has never been a square holding that the Fifth Amendment, or other prohibitions of the Constitution, are applicable to the substantive provisions of a treaty, ${ }^{239}$ the dicta are relentlessly consistent, ${ }^{240}$ and the consensus of opinion ${ }^{241}$ unflagging, in affirming this proposition. "Resting upon the fundamental grounds that it [the Fifth Amendment] does," comments Professor Corwin, "it may be confidently claimed as establishing the limits, not merely of congressional power, but of the treaty-power as well, whenever it impinges upon private rights." ${ }^{242}$ It is this restriction which unquestionably gives substance to the constantly reiterated prohibition against treaties authorizing "what the Constitution forbids." 243 What . applies to treaties is equally applicable to congressional-executive agreements. ${ }^{244}$ There is nothing in either the decision or opinion in the recent, much-mooted case

${ }^{238}$ Garner, Acts and Joint Resolutions of Congress as Substitutes for Treaties, 29 AM. J. INT'L L. 482 , 488 (r935).

The special problems that would be involved in our adherence to an International Court of Human Rights can be resolved when, and if, the occasion arises. There is considerable opinion that such a court would not offer the best technical means of implementation. H. LAuterpachr, Human Righrs, the Charter of the United Nations, and the International Bill of the Rights of Man (i945); and Preliminary Report to Internationat Law Association, Brussels Conference (i948). If, however, such a court should be decided upon, the constitutional difficulties do not appear insuperable. See Wright, Treaties and the Constitutional Separation of Powers in the United States, I2 AM. J. INT'1 I. 64, 85-90 (1918); Comment, 58 YALE L. J. Ir42, II55 (I949).

${ }^{30}$ Henry Rottschaefer, Handbook of American Constitutional Law 385 (1939); Weinfield, op. cit. stipra note 166 , at 31 .

${ }^{210}$ Geofroy v. Riggs, 133 U. S. 258, 267 (1890):

"It would not be contended that it [the treaty-power] extends so far as to authorize what the Constitution forbids ..."

Asakura v. Seattle, 265 U. S. 332, 341 (1924):

". . . it [the treaty-power] does not extend so far as to authorize what the Constitution forbids ..." See also Cherokee Tobacco v. United States, II Wall. 6I6 (U. S. I870); Browne v. Duchesne, I9 How. I83, I97 (U. S. 1856 ); Doe v. Braden, x6 How. 635, 656 (U. S. $x 853$ ); Downes v. Bidwell, I82 U. S. 244,370 (IgOI). But of. Ware v. Hylton, 3 Dall. 199 (U. S. 1796). On this point the case is probably dubious law today. See Willard B. Cowles, Treaties and Constitutional Law: Property Interferences aND DUE Process of LAw (194I), a definitive work which reviews all the cases and literature and thoroughly establishes the conclusions expressed in our text.

241 2 Burler, op. cit. supra note 166 , Section 442; Cowles, op. cit. stupra note 240; I WILloughBY, op. cit. supra note 166, Sec. 219; WeINFELd, Labor Treaties and the Due Process Clause, 6 Brook. L. REv. 338 (1937).

${ }^{342}$ Corwin, National Supremacy, op. cit. supra note 166 , at 17 .

${ }^{243}$ See note 240 supra.

24 See Guaranty Trust Co. v. United States, 304 U. S. 126, I43 (1937); United States v. Curtiss. Wright Corp., 299 U. S. 304, 320 (1936). 
of United States $v$. Pink $k^{245}$ to support a contrary conclusion. The ground for the decision in that case, which concerned the effect of an executive agreement between President Roosevelt and Litvinov, assigning the New York assets of a Russian insurance company to the United States, was that under the facts-all American creditors of the insurance company having been satisfied prior to suit by the United States-the Federal Government could in the interest of protecting general creditors of Russia in the United States be permitted to give itself priority over foreign creditors without doing violence to the Fifth Amendment. The opinion of the Court, by Justice Douglas, clearly assumed that the Fifth Amendment was applicable ("To be sure, aliens as well as citizens are entitled to the protection of the Fifth Amendment"), but urged that the Federal Government was no more barred by the terms of that Amendment from securing priority for itself and its nationals over foreign creditors than states were precluded from similar preference under the Fourteenth Amendment. ${ }^{248}$ Despite the sad plight of foreign creditors of expropriated Russian corporations, there is no doubt that the great protections of the Constitution remain for residents of the United States, citizen and alien.

Legislation implementing treaties has, moreover, been categorically declared subject to the Fifth Amendment. It is ironic that a decision upholding slavery needs be invoked to support a program for human rights. Nonetheless, in the Dred $S \operatorname{sott^{247}}$ case the issue was the constitutionality of the "Missouri Compromise," an act which pursuant to Article III of the Treaty of Cession of Louisiana ${ }^{248}$ abolished slavery (Missouri excepted) in the Louisiana Purchase area. In striking down this act Chief Justice Taney held that the taking of property in slaves without just compensation was a violation of the Fifth Amendment. It is not to be expected that the Court would today do less in the cause of freedom.

The final constitutional charge of the bar leaders that the United States is peculiarly vulnerable in international undertakings about human rights, because, unlike in many countries, its treaties if intended to be self-executing, are self-executing as laws of the land, ${ }^{249}$ is inconsequential. Even assuming that there is any danger in reaffirmation through international agreement of our respect for funda-

${ }^{245} 315$ U. S. 203 (I942).

${ }^{246} \mathrm{Id}$. at 228; see Comment, supra note 237 , at $897-899$.

${ }^{247}$ Scott v. Sanford, x9 How. $393,446-454$ (U. S. 1857 ).

${ }^{248}$ See Cowles, op. cit. supra note 240 , at $159-\mathrm{I} 76$.

${ }^{240}$ Briggs, in The Law of Natrons: Cases, Documents, and Notes 432 (1938), cites a surprising number of countries as in accord with the United States. He writes:

"In many states the constitution or constitutional practice stipulates that international law-or at least treaties-are the law of the land. This is the practice of the United States, Switzerland, France and Belgium (with qualifications), Holland, Spain, Germany (Art. 4 of the Constitution of 1919), Austria, Estonia, Egypt, Argentina, many South American States, and possibly others."

The British practice which requires an act of the executive plus approval of Parliament to make an agreement the law of the land, if it brings any changes, is in fact not too different from United States practice which requires an act of the executive plus, for agreements beyond the scope of the President's own power, the approval of the Senate or of the whole Congress. See FrAncis O. WiLcox, THE Ritipication of INTERnational Conventions 78 (1935). 
mental human rights, several remedies are ready to hand. The agreement can by its terms be made effective internally in this country only when other states similarly implement it; or reservation in such terms can be attached to our ratification; or assuming we accept immediate obligation and bad faith develops in other countries, the Congress can promptly abrogate any internal obligation. In the case of bad faith by other countries, well-hallowed doctrines of international law, such as rebus sic stantibus $^{250}$ and abrogation for failure of performance, are available to discharge even any international obligation we may have assumed.

\section{VI}

From the perspective of centuries necessary to realistic appraisal of the United Nations human rights program, it is obvious not only that it is not impolitic for the United States to participate in that program but that it would be most impolitic for the United States to fail to assume the leadership that world events have thrust upon it. The human rights program is but an integral and indispensable part of a total program designed to preserve peace and to maintain a free society for as many as possible of the peoples of the world-a program supported by the whole free world and today the principal concern of our national policy and national effort. $^{251}$ So far from being a product or hallmark of totalitarianism or statism of any kind, human rights guarantees, even when supplemented by concern for that

${ }^{260}$ See Briggs, op. cit. stupra note 249 , at 477 et seq. with citations. For the practice, legality, and technique of reservations, see Wilcox, op. cit. supra note 249, at 47; 5 GreEN H. HACKworth, Digest of International LaW ioI (I943); Harvard Research in Internattonal Law, Law of TreátTes 843 (1935); David H. Miller, Reservations in Treaties (xgig).

${ }_{261}$ It is significant that the Russian response to the human rights program has been marked by caution only comparable to that of the American bar leaders. The Declaration was found "acceptable" on the whole, but also "unsatisfactory" because among other reasons it contained no machinery for enforcement. See U. N. Document E/80o, 1948, pp. 29, 30. Yet the consistent Russian position during the 1949 Session of the Human Rights Commission was that no enforcement of Human Rights on the international level could be tolerated. In supporting this rigid and legalistic conception of "sovereignty," Mr. Pavlov has insisted before the Commission that Article 2 paragraph 7 of the Charter would be violated if any other course were taken. See U. N. Documents $E / C N_{4} /$ IIr, ro June, r $949 ; i d . /$ I $_{4}$, I6 June I949. See also Soviet Statement on Implementation Members, E/CN4/154, 24 June I948, in which all the draft proposals submitted for implementation of human rights were rejected. In a vein all too familiar, the Soviet objection reads:

"... It [the Soviet Delegation] notes that all these drafts and proposals interpret implementation to mean not a system of measures for ensuring that human rights are implemented and guaranteed in every country by the State and society, but rather, a system of international methods of pressure to be exercised through special organs established for this purpose (e.g. an international court, international committee or a United Nations public prosecutor, etc.), and intended to force individual States to take particular steps connected with execution of the Convention on Human Rights.

"It is clear, therefore, that such 'implementation' may become a means of interfering in the internal affairs of a State party to the Convention, and of undermining the sovereignty and independence of particular States. ..."

For earlier Soviet views and analysis of Soviet law see Hazard, The Soviet Union and a World Bill of Rights, 47 CoL. L. REv. 1095 (1947).

It is not to be expected that the Soviets will subscribe to many of the political rights regarded by the West as indispensable to freedom. To the extent, however, that they will agree to an authoritative formulation of rights that free peoples cherish, there is so much gain. To the extent that they refuse to agree, the lines between the objectives of the Soviets and other peoples are only more clearly drawn. 
economic opportunity without which no rights can be secure, ${ }^{252}$ are a product of our own liberal revolution and are indispensable to a free society. The basic element in any human rights guarantee is the presumption of private choice and the insistence that, in so far as is compatible with the best interests of the community as a whole, private choice be protected against coercion of any kind, from any possible source, governmental or otherwise. It is this emphasis upon private choice in all aspects of life which distinguishes a free society from totalitarianisms which rely and depend upon dictation, coercion, and violence. The greatest single issue before the world today is whether a society which emphasizes private choice as opposed to external dictation can survive. In an unorganized world faced with possible annihilation, it is a grave question whether the centuries-long trend from a coercive, caste, and immobile society toward a more and more perfectly realized democracy can be continued, or must give way to precipitous descent into the closed society of garrisonprison states, dominated by a new caste specializing in violence.

It should need no emphasis that one condition of the survival of a free society is a vision, fortified with reasonable hopes of fulfillment, by the peoples of the world of what a free society can offer. Loyalties that are not indissolubly tied to democracy can be captured by totalitarianism. It is not suggested that a human rights program alone can embody all the conditions necessary to preserve peace and a free society in the contemporary world. The total conditions of peace and a free society must include the creation of institutions and a production and distribution of values adequate to take account of all the world-wide interdependences described above. ${ }^{253}$ In terms of institutions, this means a sufficient organization of world-wide community coercion to maintain freedom from violence and aggression and to "provide a framework of policy and regulation which will permit the peoples of the world to pursue all their values by peaceful procedures." ${ }^{254}$ In terms of values, it means both a certain concentration and certain dispersal of power and "a certain balance of income and wealth, a lack of discrimination for reasons irrelevant to capacity under respect, a flow of realistic information under enlightenment, less destructive personality formation under character, a growing common standard of right under rectitude," and so on. ${ }^{255}$ The indispensable function among these conditions of a human rights program, with its enshrinement of the "deep historic ex-

${ }^{252}$ That human rights are incomplete without opportunity for economic frecdom is now axiomatic. Thus Becker, in developing the principal theme of a brilliant book, MODERN DEMrOCRACY (194I) writes (at p. 62):

"What the average man now needs is the opportunity to acquire by his own effort in an occupation for which he is fitted, the economic security which is essential to decent and independent living."

More famous is Anatole France's reference to "the majestic equality of the laws, which forbid rich and poor alike to sleep under the bridges, to beg in the streets, and to steal their bread." Quoted in ChanLEs E. Merriam, Systematto Politics 55 (1945). For excellent expositions, see Tawney, Equality (1931), and the essays by Woodward and Carr in University of Denver, Foundations for World Orden (1949).

${ }_{253}$ For development see McDougal, The Role of Law in World Politics, 20 Miss. L. J. 254 (1949). 254 Id. at 277.

${ }^{255}$ Id. at 278 . 
perience" and "moral sense of mankind" 256 into world constitutional doctrine, should be clear. Its function is to clarify the values of the people of the world in terms of the values of a free society, to reinforce their expectations that they can best maximize their own personal values in such society, to cement their loyalties to such society, to promote that consensus with respect to democratic values which will reduce to the minimum the need to use coercion to compel lawless dissenters, to further the increasing identifications of free peoples with all other free peoples, and in general to predispose the peoples of the world to the creation of the institutions necessary to survival in this atomic era. ${ }^{257}$ To recapitulate in detail the promise of such a program in terms of all of man's basic values-in providing the access to political power upon which freedom and peace depend, in promoting the flow of enlightenment necessary to sustain democratic processes, in establishing the equality necessary for recognition of common merit as a human being and special merit as an individual, and so on-is certainly here superfluous. ${ }^{258}$

To most men of good will it is obvious that the United States has peculiar responsibilities of leadership in the human rights program, not only in aid of its own survival but, because of its paramount power position among free peoples, also in aid of the survival of all such peoples. It is common knowledge that since World War II the United States has been singularly inept in formulating a comprehensive and positive moral doctrine behind which the free people of the world can unite. In Persuade or Perish, a book too little read, a distinguished writer convincingly

${ }^{280}$ H. Lauterpacht, Preliminary Report to Internationat Law Association, Brussels ConferENCE 27 (I948) (Memo U. N. Document E/CN $4 / 89,1948$ ).

${ }^{367}{ }_{x}$ For itemization of some of the beneficent effects of earlier human rights declarations, see TAwney, EQualtit 134 et seq. (1931).

A leap from the premise that since some treaties have been regarded as mere "scraps of paper" to the conclusion that any principle, enshrined in great state papers or constitutional documents, must be futile and without effects on the world power process, involves a very considerable underestimation of the role that authoritatively formulated principle can be made to play in the affairs of men.

A similar fallacy underlies the repeated suggestion that human rights stem from some source higher than government and that not only can government do little to secure them but also any effort by government to secure them is likely to endanger them. To recognize that devotion to human rights has many justifications-religious, natural law, and other-rooted deep in man's nature, it is not necessary to ignore that such rights often get scant protection in fact if they do not have government or centralized community coercion behind them. One wonders whether the opponents of the United Nations program regard the Bill-of-Rights provisions in our own Constitution as superfluous and why, in contradiction of their premises, they shudder for the fate of any rights that may be omitted from the United Nations program. Men have always sought to secure their rights by that formulation of principle and balancing of power which we call government; the alternative to government is anarchy and rule by private violence. To fail to distinguish the moral justifications for rights from the realities of the power necessary to protect them is simple, and perhaps suicidal, intellectual confusion.

${ }_{258}$ It will be observed that the case we make is not so much for the latest draft of the proposed Covenant on Human Rights, though we think it good so far as it goes, as for the kind of Covenant that the United States should establish as its goal. It is our judgment after detailed analysis, recital of which is not necessary to our present purposes, of both the Genocide Convention and the draft Covenant on Human Rights, that they in no way "change, but rather re-enunciate, standards which we have professed in this country since the Civil War. Hence any criticism we might make of the content of the proposed agreements would be, not for their inclusions, but for their omissions-for their failure to incorporate, and perhaps even to raise, more of the standards which we and other free peoples profess to honor and to regard as necessary for survival. 
urges that "it is hardly an exaggeration that we must persuade or perish," must produce a positive, world-encompassing faith or find ourselves isolated even from other free peoples. The human rights program offers us an opportunity, unparalleled in its potentialities, to assume and give concreteness to the moral leadership incumbent upon us. ${ }^{260}$

So much misconception is abroad, it may bear emphasis that participation by the United States in this United Nations program for securing human rights imports no revolutionary changes in our form of government, increases no dangers of federal absolutism, and shifts no real power from the states to the Federal Government that the course of events has not already shifted. ${ }^{261}$ The truth is that the social and economic, and hence constitutional, structure of the United States has had nc immunity from the forces that have made for interdependence in the world at large. The same forces that operate to make the world one, operate even more intensely to make this nation one, not only as to foreign affairs and domestic economy, but as to all values: the degree of democracy in participation in power processes; the sanctity, freedom from arbitrary restraint, and well-being of the individual human being; the free flow of enlightenment; and so on. For several decades this national unity and interdependence in fact have found expression at an accelerating tempo in our formal constitutional doctrine. Concomitant with the expansion of federal power through interpretation of the commerce and other clauses, ${ }^{202}$ has come a striking increase of federal supervision over civil rights and liberties. ${ }^{203}$ More and

250 Wallace Carrol, Persuade or Perish 389 (1948).

${ }^{200}$ The fear, so dramatically emphasized by the bar leaders, that the United States might by entering into new agreements expose itself to a losing battle of mutual recriminations with the Russians is idle. Our practices are not so vulnerable as such fear implies; such a battle is possible under the present United Nations Charter and is going on; and there is no reason to assume that our own diplomats would be disadvantaged by having a new set of premises, assuming that the Russians subscribe, for inquiring into some of the obscurities of Russian practice. The newspapers have indeed been filled recently with stories about some questions of slave labor and of violations of human rights in Russian satellite countries. More positively we have, as indicated above, in the symbols of frecdom, democracy, and equality instruments of potentially tremendous power for capturing and holding the loyaltics of peoples; to leave these symbols to the exploitation of others, who in fact make a mockery of them by denying access to the very values that make them meaningful, can only be folly. Our national concern must be, not so much for Russian criticism, as for what the rest of the world really, and should deservedly, think of us. In the words of the President's Committee on Civil Rights, To Secure TinesB Rigrrs 148 (1947): "The United States is not so strong, the final triumph of the democratic idenl is not so inevitable that we can ignore what the world thinks of us or our record."

261 "The advajnce of federal power, however much we may regret," one writer observes, "scems to have been in the main as inevitable as the advance of science which produced it." Grcen, The Supreme Court, the Bill of Rights and the States, 97 U. OF PA. L. REv. 608, 615 (1949).

${ }_{202}$ See Green, stipra note 261, at 614-615; Fellman, Recent Tendencies in Civit Liberties, Decisions of the Supreme Coutt, 34 Cons. L. Q. 33I, 332 (1949).

${ }^{203}$ For notable articles among many on this subject, see Lusky, Minority Rights and the Public Interest, 52 YALE L. J. I (1942); Berger, The Sutpreme Court and Groutp Discrimination Since 1937. 49 Col. L. Rev. 20I (1949); Green, supra note 26r; Green, The Bill of Rights, The Fourteenth Amendment and the Supreme Court, 46 Mich. L. R'Ev. 869 (1948); Fellman, supra note 262; Bosky and Pickering, Federal Restrictions on State Criminal Procedure, I3 U. of CHI. L. Rev. 266 (1946); Comment, The Adamson Case: A Study in Constitutional Technique, 56 YALE L. J. 268 (1949). Sec also for morc general surveys of the problem: Milton R. Konvitz, The Constitution and Civil Rights (1947); Robert K. Carr, Federal Protection of Civil Rigits: Quest for a Sword (1947); and Fraenkel, The Federal Civil Rights Law, 31 MinN. L. Rev. 301 (I947). 
more the Supreme Court has conceived and established itself, under a great variety of constitutional provisions, as a unifying and norm-setting agency for the entire nation. ${ }^{204}$ The national interest that this development continue, with legislative support, has been demonstrated by many observers and is the official platform of both major political parties. ${ }^{285}$ The same considerations that make human rights of world-wide concern as among nations apply, with all the added intensity of the forces operating for national interdependence, to make such rights of nation-wide concern for our people.

To dispel fears of novelty in the human rights program, the trend in decision by the Supreme Court to establish national standards may be indicated in detail. The chief vehicle for development has been the Fourteenth Amendment, expanded both in its application to parties and in the scope of rights protected. The criterion of what constitutes "state" action in the application of this Amendment has been progressively broadened, culminating in decisions finding "state" action in unauthorized acts of state officials, ${ }^{266}$ in determinations of political parties, ${ }^{267}$ in exclusions from company towns, ${ }^{268}$ and in the enforcement of restrictive covenants by state courts. ${ }^{269}$ The scope of the Fourteenth Amendment as applied against the states has been widened notably also through incorporation, beginning in $\mathrm{rg27}$, of all the political activity freedoms of the First Amendment (freedom of speech, press, assembly) as well as freedom of religion and freedom to petition Congress for redress of grievances. ${ }^{270}$ Moreover, the area of freedoms outside the First Amend-

204 An illuminating discussion of this process is to be found in Lusky, supra note 263 , especially at 13-21. See also Hamilton and Braden, The Special Competence of the Supreme Court, 50 YALE L. J. I3I9, 1349 (194I).

${ }_{205}$ Republican Party Platform, June 22, 1948; Democratic Party Platform, July 14, 1948.

Among the better statements of the national interest are Lusky, supra note 263; ToM C. CLARK AND Philip B. Perlann, Prejudice and Property (1948), the brief for the United States as Amicus Curiae in Shelley v. Kraemer, 334 U. S. I (1948); Report of the PRestdent's ConitTtee on Civil Rights, To Secure These Rights (r947). For some reflection of the prevailing public concern for these questions, see the extensive list of organizations which filed briefs Amicus Curiae in the Shelley case, supra; Ming, Racial Restrictions and the Fourteenth Amendment: The Restrictive Covenant Cases, 16 U. OF CHI. L. REv. 203, 205 n. 6 (I949).

Lusky, supra note 263 at $18-19$, after detailed consideration of many aspects of national interest summarizes:

"The justification for Federal intervention in the field is therefore clear. There is a national interest not only in preserving a form of government in which men can control their own destinies, but in enabling the common man to see its advantages and know its feasibility. It is an interest in quelling doubts as to the practical efficacy of our system to accomplish essential justice. It is an interest in preventing deviations from our national ideal, even in local government, because deviations create such doubts. In short, it is an interest in making a belief in our system a part of the American creed."

${ }^{200}$ Screws v. United States, 325 U. S. 9I (1945). See KonviTz, op. cit. stipra note 263, at 49-90; CArR, op. cit. supra note 263 , at II2-114.

${ }^{207}$ Smith v. Allwright, 32x U. S. 649 (1944); Elmore v. Rice, 72 F. Supp. 516 (E. D. S. C. 1947), aff'd 165 F. 2 d, 387 (C. C. A. 4th 1947), cert. denied, 333 U. S. 875 (I948). For a comprehensive treatment of "state" action see Hale, Rights Under the Fourteenth and Fifteenth Amendments Against Injuries Inflicted by Private Individuals, 6 Law. Guild Rev. 627 (I946).

${ }^{208}$ Marsh v. State of Alabama, 326 U. S. 501 (1946).

${ }^{200}$ Shelley v. Kraemer and McGee v. Sipes, 334 U. S. I (1948). See Ming, Racial Restrictions and the Fourteenth Amendment: The Restrictive Covenant Cases, I6 U. of CHI. L. Rev. 203 (1949).

${ }^{270}$ Free Speech and Press: Gitlow v. People of New York, 268 U. S. 652 (I924) (dictum); Fiske 
ment and not yet enforceable against the states is visibly contracting. Indication of the trend is the continuing debate launched in the Adamson ${ }^{271}$ case concerning the "incorporation" in toto of the Bill of Rights into the due process clause of the Fourteenth Amendment. Justice Black, joined by three other Justices, ${ }^{272}$ wrote a challenging dissent in that case and demonstrated with a compelling array of facts the unmistakable intention of the sponsors of the Fourteenth Amendment to make the Bill of Rights applicable through it to the states. ${ }^{273}$ The majority, on the other hand, felt impelled to favor the "fair trial" rule which in effect confines strict protection of the privilege against self-incrimination (or any other appropriate safeguard of the Bill of Rights), through "incorporation" into the Fourteenth Amendment of the Fifth or other corresponding Bill-of-Rights Amendments, to those cases in which failure to enforce a Bill-of-Rights prohibition "would be lacking in fundamental fairness, shocking to the universal sense of justice."274 Nevertheless, the incorporation rule was again advanced in a concurring opinion by Justice Rutledge in In re Oliver, ${ }^{275}$ a case holding Michigan's one man jury system responsible for violation of the requirement of a public trial. ${ }^{276}$ While the "fair trial" rule is never an absolute bar to a selective incorporation-case by case-or independent determination of the rights of the suspect, accused and convicted, ${ }^{277}$ it nevertheless obscures the extent to and certainty with which Fourth, Fifth, Sixth, and Eighth Amendment

v. Kansas, 274 U. S. 380 (r927) (square holding). Assembly: De Jonge v. Oregon, 299 U. S. 353 (1937); see also Herndon v. Lowry, 30 I U. S. 242 (r937); Hague v. CIO, 307 U. S. 496 (1939). Religion: Cantwell v. Connecticut, 3 Io U. S. 296 (1940); but see Prince v. Massachusetts, 321 U. S. 158 (1944) (for adults only). Prohibition against establishment of religion: Illinois ex rel. McCollum v. Board of Education, 333 U. S. 203 (1948); compare Everson v. Board of Education, 330 U. S. I (1947). Petition of government for redress of grievances: Bridges v. California, $3{ }_{4}$ U. S. 252 (194I). See Green, supra note $26 \mathrm{r}$ passim.

${ }^{271}$ Adamson v. California, 332 U. S. 46 (1947). See Comment, stipra note 263.

${ }^{272}$ Justice Douglas concurred in Justice Black's opinion, while Justice Murphy, joined by Justice Rutledge, wrote a separate dissent in which he approved Black's position excepting only the novel limitation that the first section of the Fourteenth Amendment is limited by the Bill of Rights. Id. at I24.

${ }^{273} \mathrm{Id}$. at 68 and 92 et seq.

The original view was well expressed by Justice Harlan's famous dissent in the Civil Rights Cases, rog U. S. 3, 26 ( 1883 ): "I cannot resist the conclusion that the substance and spirit of the recent amendments of the Constitution have been sacrificed by a subtle and ingenious verbal criticism. . . . Constitutional provisions, adopted in the interest of liberty, and for the purpose of securing, through national legislation, if need be, rights inhering in a state of freedom, and belonging to American citizenship, have been so construed as to defeat the ends the people desired to accomplish .... which they supposed they had accomplished by changes in their fundamental law." $C f$. Watt and Orlikoff, The Coming Vindication of Mr. Justice Harlan, 44 InL. L. Rev. ${ }_{3}$ (1949).

${ }^{274}$ Betts v. Brady, $3 \times 6$ U. S. 455,462 (I942). The "fair trial" rule was first introduced in this case, which involved denial of the right to counsel under the Sixth Amendment.

${ }^{270} 333$ U. S. 257 ( 1948 ).

${ }^{270}$ The conflict in the Court between the incorporation rule and the fair trial rule continues unabated. See the dissents similar to those in the Adamson case in Foster v. Illinois, 332 U. S. 134 (1947); Gnyes v. New York, 332 U. S. $x 45$ (1947); Bute v. Illinois, 333 U. S. 640 (1948). And the more recent, Gibbs v. Burke, 69 Sup. Ct. 1247 (1949), in which Justices Black and Douglas concur in the finding that a fair trial had been denied in an issue involving the right to counsel, but explicitly state that they "think Betts v. Brady should be overruled." $I d$. at 1251 .

${ }^{277}$ See e.g., Uveges v. Commonwealth of Pennsylvania, 69 Sup. Ct. I84 (1949) (failure to provide counsel for I7 year old boy held denial of due process). 
protections are specifically applicable to the states. ${ }^{278}$ But even this confusion does not interrupt the general trend toward federal supervision. Notice of accusation and an impartial tribunal are conceded an essential part of due process, ${ }^{279}$ and federal prohibition against coerced confessions in state courts has been recognized since Brown v. Mississippi in $19366^{2 s 0}$ Other decisions on the scope of the Fourteenth Amendment, not involving the incorporation of the Bill of Rights, show similar trends. In recent terms, equal protection has been widened by decisions invalidating discriminatory presumptions in state alien land laws, ${ }^{281}$ and prohibitions against issuance of commercial fishing licenses to persons ineligible to citizenship; ${ }^{282}$ and by a narrowing of the equal but separate facilities rule through the requirement that educational facilities be furnished as promptly for Negroes as for other groups. ${ }^{283}$ The range of topics included within the scope of the Fourteenth Amendment as amplified by the First Amendment enlarges continuously also. Freedom of speech and press includes freedom from postal censorship, ${ }^{284}$ peaceful picketing, ${ }^{285}$ and, more recently, freedom to use loud-speakers in public streets, ${ }^{\mathbf{2 8 6}}$ and to publish despite an indefinite prohibitory statute "stories of bloodshed, lust or crime."287 To these growing national standards, may be added the fact that in determining the constitutionality of a statute, the Supreme Court no longer abides by the traditional presumption in favor of the statute where civil rights are concerned, ${ }^{288}$ thus perceptibly increasing federal supervision. The commerce clause too has been a means to national standards. Two notable cases are Edwards $v$. California ${ }^{289}$ and Morgan v. Virginia, ${ }^{290}$ where it was held that interstate commerce was burdened by state laws forbidding transportation of indigent persons into the state of California, in the first case, and segregating Negroes in busses traveling in interstate commerce, in the second. From this review, it is apparent that any shift in formal authority from

${ }^{278}$ On searches and seizures, see Wolf v. Colorado, 69 Sup. Ct. 1359,1364 (I949) (Fourteenth Amendment does not absorb this Fourth Amendment protection). The direct application of the double jeopardy prohibition to states was assumed but not decided in Louisiana v. Resweber, 329 U. S. 459 (1947), a capital case, in which a second electrocution was held not to be double jeopardy nor to infringe the prohibition against cruel and inhuman punishments.

${ }^{270}$ See Holden v. Hardy, I69 U. S. $366,389-390$ ( 1898 ); Cole v. Kansas, 333 U. S. 196 (1948). See Green, supra note 26I, at 637. For confrontation of witnesses, see Snyder v. Massachusetts, $29 \mathrm{I}$ U. S. 97, I3I (1934).

${ }_{280} 297$ U. S. 278 (1936); Chambers v. Florida, 309 U. S. 227 (1940); but see Lisenba v. California, 314 U. S. 219 (194r). In the past term of the Court see Watts v. Indiana, 69 Sup. Ct. I347 (1949); Turner v. Commonwealth of Pennsylvania, 69 Sup. Ct. 1352 (1949); Harris v. South Carolina, 69 Sup. Ct. 1354 (1949).

${ }_{281}$ Oyama v. California, 332 U. S. 633 (1948).

292 Takahashi v. Fish and Game Commission, 334 U. S. 4 ro (1948).

${ }^{283}$ Sipuel v. Board of Regents, 332 U. S. 63 I (1948).

${ }^{284}$ Hannegan v. Esquire, 327 U. S. I46 (1946).

${ }^{285}$ Thornhill v. Alabama, 3 10 U. S. 88 (1940). But see Giboney v. Empire Storage \& Ice Co., 69 Sup. Ct. $68_{4}$ (1949). ${ }_{280}$ Saia v. New York, 334 U. S. 558 (1948); but see Kovacs v. Cooper, 69 Sup. Ct. 448 (I949). ${ }^{287}$ Winters v. New York, 333 U. S. 507 (I948).

${ }^{288}$ See Justice Stone in United States v. Carolene Products, 304 U. S. I44, 152, n. 4 (I938). See also Fellman, stipra note 262 , at 348 . ${ }^{280} 314$ U. S. I60 (I94I).

${ }^{280} 328$ U. S. 323 (1946). 
the states to the Federal Government that might occur by our joining in an international covenant to secure human rights could only anticipate a development already rapidly going forward under other powers, a development which promises a comprehensive structure of constitutional doctrine, national in its application and adequate to secure the national interest.

It may, in conclusion, be emphasized that the bar leaders' recommendation of the slow approach to human rights, that it is better to await the evolutionary processes of customary law and not to use agreement, that international law cannot be made in the "twinkling of an eye," misconceives every factor upon which such recommendation is based: misconceives the intimate interdependences, if not identity, of human rights and security, the world-wide interdependences of peoples everywhere; misconceives our obligations under the United Nations Charter, the potentialities of new agreement, and even the reach of traditional, customary' international law, with its fundamental and continuous concern for the welfare of the individual human being; misconceives both the scope of federal power under our Constitution over matters of international concern and the safeguards imposed by the Constitution on the exercise of such power; and, finally, misconceives the indispensability of human rights protection to a free society and the degree to which this nation is becoming, and must be, "one" for human rights as for other values. To go slow upon any measure which promises to enhance security, whether conceived as freedom from simple physical violence or as a broader freedom to pursue all values by democratic procedures, may in the contemporary world context be to invite destruction. A human rights program alone cannot preclude atomic or bacteriological catastrophe, but such a program can bring compellingly to the focus of world attention the needs and aspirations of mankind in terms of human dignity and may, by cementing loyalties to free society, be able to mobilize such aspirations in aid of security rather than destruction. The people of the United States, with their existing high standards for the protection of human rights, can have nothing whatsoever to lose by a program designed to raise standards everywhere. "The argument that the time is not ripe for extending the rule of law in relation to this or that proposal," an English writer urges apropos human rights, "appears to me unsound. Time is a forelock and, after great wars and great upheavals, that forelock hangs out like a bell-rope and needs to be pulled."201 It can be rational only for the United States acting promptly and effectively after its great traditions to assert leadership in giving time's forelock a world-resounding ring.

${ }^{291} \mathrm{~W}$. Harvey Moore in discussion of International Law and Rights of the Individual, $3 \mathrm{I} \mathrm{Tn}$. oF Gror. Soc. I06 (1945). 